Portland State University

PDXScholar

$11-15-1987$

\title{
The Effect of Cold Acclimation on the Temperature Preference of the Goldfish, Carassius auratus, and the Brown Bullhead, Ictalurus nebulosus
}

Alfred Lord

Portland State University

Follow this and additional works at: https://pdxscholar.library.pdx.edu/open_access_etds

Part of the Biology Commons, and the Physiology Commons Let us know how access to this document benefits you.

Recommended Citation

Lord, Alfred, "The Effect of Cold Acclimation on the Temperature Preference of the Goldfish, Carassius auratus, and the Brown Bullhead, Ictalurus nebulosus" (1987). Dissertations and Theses. Paper 3736. https://doi.org/10.15760/etd.5620

This Thesis is brought to you for free and open access. It has been accepted for inclusion in Dissertations and Theses by an authorized administrator of PDXScholar. Please contact us if we can make this document more accessible: pdxscholar@pdx.edu. 
AN ABSTRACT OF THE THESIS of Alfred Lord for the Master of Science in Biology presented November 15, 1987.

Title: The Effect of Cold Acclimation on the Temperature Preference of the Goldfish, Carassius auratus, and the Brown Bullhead, Ictalurus nebulosus.

APPROVED BY MEMBERS OF THE THESIS COMMITTEE:
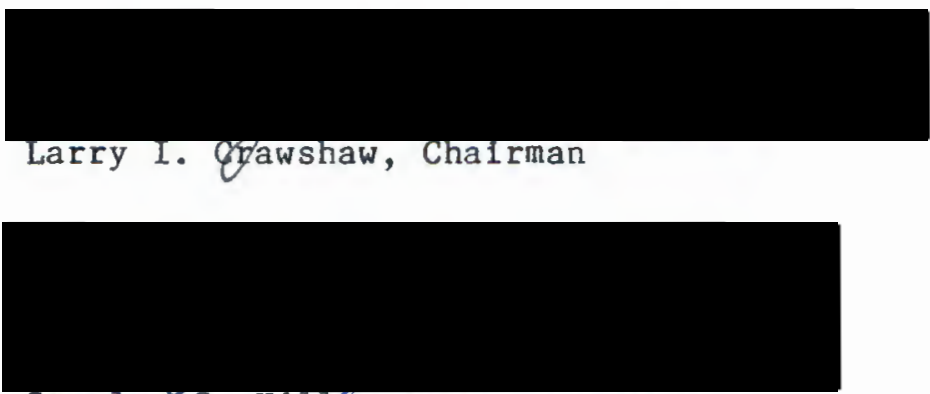

Stanley S. Hilfman

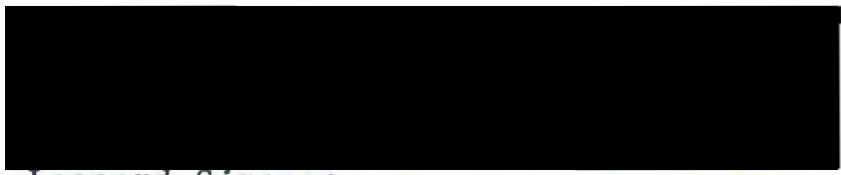

Leonard Simpson

Two species of fish, Carassius auratus and Ictalurus nebulosus, were subjected to cold acclimation regimes. Acclimation temperatures were slowly lowered to $3^{\circ} \mathrm{C}$, then held 
for a period of time. At various times during this regime, fish were taken out and allowed to spend time in a temperature gradient to determine their preferred temperatures. Carassius were left in the gradient fust long enough to determine a measure of the acute temperature preference, while Ictalurus were left in the temperature gradient for longer periods of time to observe any changes that might occur as the fish adjusted to selected temperatures. In both species of fish, lower acclimation temperatures and increased time spent at low temperatures caused a preference for lower temperatures in the gradient.

Numerous factors may be involved in the process of acclimation, and it is difficult to positively implicate physiological processes with any aspects of acclimation observed here. However, the slow, sporadic increase in Ictalurus preferred temperature, taking place over several hours, indicates that an important physiological change is occurring. Different acclimation groups showed dissimilar rates of temperature preference increase through the same temperature ranges. It seems most likely, due to the time periods involved, that a change in either enzyme or membrane lipid structure may be occurring, while additionally, the fish must overcome difficulties posed by varlable $\mathrm{pH}$ and oxygen uptake levels that occur as body temperature changes. 
THE EYFECT OF COLD ACCLFMATTOH

ON THE TEMPERATURE FREFFRENCE

OF THE GOLDFISH, Gazassibs auratus,

AND THE BROWN BULLHEAD, Ictalurus nebulosus

\begin{abstract}
by
ALFRED LORD

A thesis submitted in partial fulfiliment of the requirements for the degree of
\end{abstract}

MASTER OF SCIENCE.

in

BIOLOGY

Portland State Jniversity 


\section{TO THE OFEICE OF GRADUATE STUDIES AND RESEARCH:}

The nembers of the Comittee approve the thesis of Alfred Lord preserted November $15,1937$.
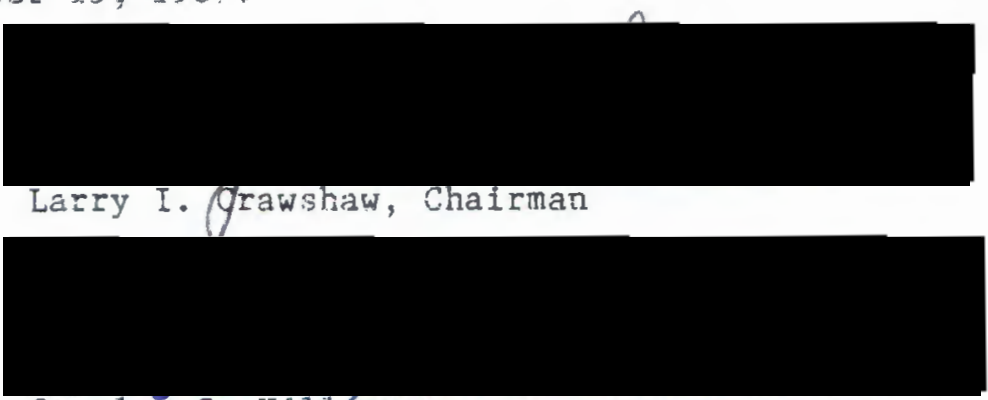

Stanley S. Hithar

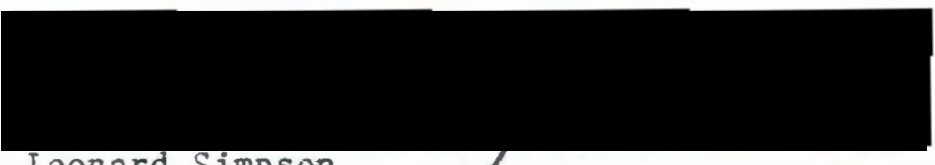

Leonard Simpson

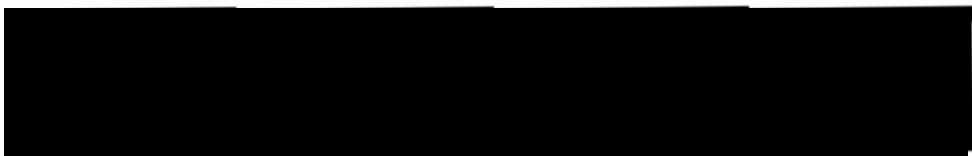

Cord Sengstake

APQROVED:

Richard R. Pgterson, Head, Department of Biology

Bernard Ross, Vice Provost of Graduate Studies 
TABLE OF CONTENTS

PAGE

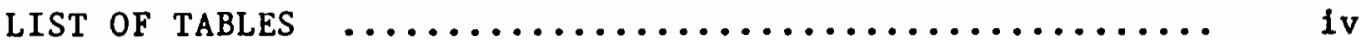

LIST OF FIGURES $\ldots \ldots \ldots \ldots \ldots \ldots \ldots \ldots \ldots \ldots \ldots \ldots \ldots \ldots \ldots \ldots \ldots$

CHAPTER

I INTRODUCTION $\ldots \ldots \ldots \ldots \ldots \ldots \ldots \ldots \ldots \ldots \ldots \ldots \ldots \ldots$

I I MATERIALS AND METHODS $\ldots \ldots \ldots \ldots \ldots \ldots \ldots \ldots \ldots \ldots . \ldots . \ldots$

Carassius auratus $\quad \ldots \ldots \ldots \ldots \ldots \ldots \ldots \ldots \ldots \ldots \ldots$

Ictalurus nebulosus $\ldots \ldots \ldots \ldots \ldots \ldots \ldots \ldots \ldots \ldots . \ldots . \ldots 24$

III RESULTS $\ldots \ldots \ldots \ldots \ldots \ldots \ldots \ldots \ldots \ldots \ldots \ldots \ldots \ldots \ldots \ldots$

IV DISCUSSION $\ldots \ldots \ldots \ldots \ldots \ldots \ldots \ldots \ldots \ldots \ldots \ldots \ldots \ldots$

Summary $\quad \ldots \ldots \ldots \ldots \ldots \ldots \ldots \ldots \ldots \ldots \ldots \ldots \ldots \ldots$

BIBLIOGRAPHY $\quad \ldots \ldots \ldots \ldots \ldots \ldots \ldots \ldots \ldots \ldots \ldots \ldots \ldots \ldots \ldots \ldots \ldots \ldots$

APPENDIX $\quad \ldots \ldots \ldots \ldots \ldots \ldots \ldots \ldots \ldots \ldots \ldots \ldots \ldots \ldots \ldots \ldots \ldots \ldots \ldots$ 


\section{LIST OF TABLES}

TABLE

PAGE

I Mean temperature selected by Individual

Carassius, along with treatment mean

and standard error $\ldots \ldots \ldots \ldots \ldots \ldots \ldots \ldots \ldots$

II Results of Analysis of Varlance on

Carassius data $\ldots \ldots \ldots \ldots \ldots \ldots \ldots \ldots \ldots \ldots \ldots$

II Latency of Temperature Selection

Increase in Ictalurus $\ldots \ldots \ldots \ldots \ldots \ldots \ldots \ldots \ldots$

IV Change in Standard Error and Activity

Levels When Ictalurus Begins Rapid

Increase of Selected Temperature $\ldots \ldots \ldots \ldots \ldots$

$V$ Analysis of Linear Slope Portion of

Ictalurus' Return to

Final Preferendum $\ldots \ldots \ldots \ldots \ldots \ldots \ldots \ldots \ldots \ldots \ldots$ 


\section{LIST OF FIGURES}

FIGURE

PAGE

1. Example of tolerance zone $\ldots \ldots \ldots \ldots \ldots \ldots \ldots \ldots$

2. Histograms of temperature selection for

individual Carassius in gradient $\ldots \ldots \ldots \ldots \ldots$

3. Change in Carassius acute preferred

temperature with acclimation temperature $\ldots . . .30$

4. Effect of time in acclimation regime

on Carassius' acute temperature

selection

5. Carassius acute preferred temperature

during $3^{\circ} \mathrm{C}$ acclimation

6. Acute preferred temperature of Ictalurus

after 24 hours at various

acclimation temperatures

7. Acute preferred temperature of Ictalurus

after various times at $3^{\circ} \mathrm{C} \quad \ldots \ldots \ldots \ldots \ldots \ldots$

8. The return of Ictalurus toward

the final preferendum in the

gradient 
9. The effect of $3^{\circ} \mathrm{C}$ acclimation on

Ictalurus' return toward

the final preferendum $\ldots \ldots \ldots \ldots \ldots \ldots \ldots \ldots$

10. The effect of acc1imation temperature on

Ictalurus' return toward

the final preferendum 


\section{CHAPTER I}

\section{INTRODUCTION}

For animals living in a thermally variable environment, it is necessary that there be some way to compensate for the temperature changes found both minute to minute and season to season. This is particularly so for polk1lotherms, which must deal with the problem at the level of molecular reactivity within their blochenical systems. Numerous examples of animal compensation for temperature change have been described. For Instance, if a fish acclimated to one temperature is suddenly moved to a warmer environment, there is a greater than expected increase in oxygen consumption. Then, over a period of hours or days, it will drop back down to a new level, representing acclimation to the new temperature (Klicka, 1965). However, more systematic measurements of the time course of this change are needed. These could help to indicate the varlous processes at work during acclimation.

The ab1lity to produce isozymes, enzymes with slight structural differences that allow adaptive reactivity changes at various temperatures, Is thought by many to be an important aspect of the polkilotherm's ability to acclimate to different temperatures. Numerous examples of isozyme production have been found, with the experimental technique of gel electrophoresis most commonly ut 1lized. For example, Bolaffi and Brooke (1974) noted that the relative concentration of the "A" subunit of lactate dehydrogenase in 
skeletal muscle increased after acclimation to warmer temperatures. The higher concentrations of this subunit, belleved to increase enzyme efficiency at the high pyruvate concentrations expected because of increased glycolysis required by high temperatures, would thus be adaptive. These results were confirmed by Kent and Hart (1976), who found an Increase in the frequency of the subunit in warm acclimated animals. They also discovered two bands of subunits not before described in the electrophoresis of Glucose-6-Phosphate dehydrogenase from warm acclimated fish. Photoperlod was found to have an effect on the distribution of some of these enzyme subunits. Shaklee et al. (1977) measured the activity and electrophoret ic properties of enzymes from muscle, liver, heart, eye and brain $t$ issue of Lepomis cyanellus acclimated to a variety of temperatures. They found a tendency for the enzyme activity changes to follow functional groupings. For instance, the enzymes succinate dehydrogenase, cytochrome oxidase and cytochrome citrate, all from the Krebs cycle and electron transport chain, increased their activity after cold acclimation. This Increase, well def ined in nervous tissue, Indicates increased metabolite breakdown. However, they found 11ttle evidenœ of Isozymic changes in the proteins looked at, instead assert ing that activity changes were due to other factors. They suspect that the multiple 1sozyme profiles seen in other studies are due to the polyploid make-up of the genome of some flsh, particularly Carasssius auratus.

Another important feature of cellular structure, the ubiquitous 1ipid bilayer, shows changes with temperature. This is usually described as an increase in membrane fluidity (decreased viscosity) with an increase in 
temperature. Since decreased saturation of the fatty chains in the 11pid molecules results in a lower melting point, it seems reasonable that such a change would come about during cold exposure. Cossins et al. (1977) measured the viscosity of membrane l1p1ds of synaptosomes from Carassius auratus and found decreases in viscosity and fatty acid chain saturation after acclimation to low temperatures. In this important cellular component, increased fluidity would counter the congealing effect of low temperatures. It would be expected, due to the necessity of molecular synthesis, that this form of acclimation would take an appreciable amount of time to occur.

The ability to effect changes at the molecular level of biological activity is complemented by a behavioral thermoregulatory system. The existance of this system indicates that an adaptive advantage to users must be present, most likely the ability to maintain optimal conditions for muscular strength, neural coordination and other functions that aid survival. In poikilotherms, the primary method of achieving this end is through habitat selection. Thus CNS activity and resulting behaviors usually result in a relatively stable body core temperature when an an 1mal is placed in a situation of temperature choice, assuming other factors, such as fear or hunger do not override the thermoregulatory system. This temperature is called the "preferred temperature". This preferred temperature changes with acclimation, or previous thermal experience. AnImals acclimated to cold temperatures do not go immediately to temperatures in which they are usually found, but are instead held back from too great a change from the acclimation temperature. This gives rise to another term for temperature 
preference, to be referred to as the acute preferred temperature. This temperature is temporally unstable and is most accurately measured within a short time of the animal's previous acclimation regime. The reason for this seems to be that each animal has a "final preferendum", a temperature which it will choose after a time long enough for acclimation to take place at or near that temperature. In other words, when the acutely preferred temperature is equal to the acclimation temperature, the animal is at its final preferendum. This temperature is of ten near the highest tolerated temperature. The ecological importance of this temperature is hinted at in a review of published data by Jobling (1981). Good correlation was found between reported values for the final preferendum and temperatures that promote optimal growth.

If temperature preference data taken from active, thermoregulating polkilotherms are complled in the form of a frequency histogram, the shape generated is usually negatively skewed. This means that the animal spends more $t$ ime at temperatures a given amount below the mode of the frequency curve than at temperatures the same amount above the mode. Because of this, It may be that the most accurate measure of the animal's preferred temperature is the mode rather than the arithmetic average of the data. The reasons for the skewness of the histograms have frequently been discussed. One fairly obvious reason for a blas toward cooler temperatures is that since the preferred temperature is near the upper limits of temperature tolerance, a negative skew will occur as a fish moves through acceptable temperatures, while maintaining the high average body temperature. Also involved, may be 
the fact that as temperatures increase, the chemical processes that maintain Iife become faster, resulting in increased movement, awareness and response levels. As these functions decrease in colder temperatures, the animal would be spending more time in cold water. It would also seem that movement, such as exploratory behavior, could bring the animal to a fairly low temperature without distress, while movement just a little above the preference point would be quickly stressful. Dewitt (1967) pointed out that at lower temperatures, behavioral function may not be as precise, resulting in decreases in both awareness and maximum swimming speed, along with increased response times. These all probably increase the negative skew seen in temperataure preference data.

In a review of published final preferendum data, Mathur et al. (1981) found that the acute preference of $\mathrm{fish}$ is more dependent on acclimation temperature than other suspected variables such as author/method differences, geographical location of source fish and species. Since acclimation temperature significantly affects preferred temperature in many species of $\mathrm{fish}$, it seems likely that the acclimatory process may be physiologically based, an obligate result of temperature change. Shrode et al. (1982) found that the acute temperature preference of California Embiotocidae and Scorpaenidae species captured was very close to that of the water in which they were captured, where a naturally formed vertical thermal gradient had occurred. This indicates that the fish (except for two anomolous species) had distributed themselves in the natural gradient to achieve their final preferendum. Thus temperature was an important factor in 
determining their behavior in the wild.

A linear relationship between acclimation temperature and acute preferred temperature usually exists in the lower temperature ranges. That relationship becomes a complex curve as temperatures approach the final preferendum (Reynolds and Casterlin, 1979). If left in a temperature gradient for an extended period of time, a cold acclimated animal will gravitate toward the final preferendum by increasing its temperature preference. This process may be considered to start at the time the animal is first given a chance to move toward the final preferendum, and may be measurable after as little time as 2 hours (Crawshaw, 1975).

Apparently, however, not all temperature effects take this long to occur. For example, alterations of molecular conformation can occur instantaneously with a critical temperature change. An example of this "Instantaneous" acclimation occurs in some enzymes that change their affinity for substrate with changes in temperature. Hazel and Prosser (1974) cited examples in which the measured $K_{m}$ decreased with temperature in enzyme substrate interactions. Since $\mathrm{K}_{\mathrm{m}}$ is an in vitro measure of the quantity of substrate needed for a given quantity of enzyme to react at half the maximal rate possible for that enzyme sample, a decrease in the value could be interpreted as an increase in substrate affinity with decreased temperature, an instantaneous temperature compensation at the molecular level. The fact that many functional proteins are associated with, or embedded in various cell membranes, the structure and fluidity of which changes with temperature, gives credence to another possible mechanism of 
instantaneous acclimatory change. Hazel (1972) measured the $\mathrm{K}_{\mathrm{m}}$ of succinate dehydrogenase at varlous temperatures and found that it decreased as the temperature decreased, but that the magnitude of this decrease was lessened by solubilizing the 11pid membrane structure in which this enzyme is embedded. Further, he found no differences between the molecular propertles of the enzymes from fish acclimated to different temperatures, after dissociation from the lipid membrane. He concluded that 1sozymal differences were probably not important in succinate dehydrogenase acclimation mechan1sms. It seems that either temperature induced conformat lonal changes of the protelns themselves, or conformational changes induced by membrane changes can be responsible for some of the Immediate acclimatory changes seen during the response to temperature change. Hazel and Prosser (1974) also point out that other modulating molecules may be present which could change the functional propert les of proteins with temperature.

However, acclimation is usually thought of as a process that takes some time, even weeks to occur. The thickening and color changes of some mammallan pelages in preparation for winter is one such change. The changes in gene expression, of ten cited as an important mechanism of acclimation, probably could begin to occur within hours, although longer perlods, probably days, would be required for completion of the process. Caldwell (1969) measured cytochrome oxidase activity from gill, nervous, and muscle tissue of Carassius auratus after cold acclimation for a period of 2 to 4 weeks. In each of these $t$ issues, but not in hepatic $t$ issue, there was increased cytochrome oxidase activity in response to cold exposure. Similarly, sidell 
et al. (1973) measured the activity changes of cytochrome oxidase and succinic dehydrogenase from the epaxial muscle of Carassius. Cold acclimation caused an increase in activity, while warm acclimation had the opposite effect on cytochrome oxidase activity. They noted a highly variable response during the first one to two weeks, and stabilization at new levels occurred after 21 to 24 days. Unfortunately, the tests were performed at random times after the start of the acclimation regime, and analysis of any potential cyclic patterns in enzyme activity before stabilization showed no significance. However, the possibility exists that some diurnal or other, shorter period (ultradian) cycle may have had an effect on enzyme activity or some other aspect of the method used in this experiment. Smit et al. (1974) measured the oxygen uptake of mitochondrial fractions of red muscle homogenates from fish acclimated at $15^{\circ} \mathrm{C}$. This was done by bathing the fraction in solutions containing $\mathrm{Na}$-succinate as a substrate, while measuring the decrease in oxygen content of the solution. Oxygen uptake measurements were then taken at weekly intervals for 6 weeks after moving the fish to a higher temperature. After an apparent overshoot starting at about three weeks, the activity stabilized after 5 weeks at about half the activity of the $15^{\circ} \mathrm{C}$ fish. Similar rate changes have been seen in organismal oxygen uptake during rapid warming, although the time course is a bit shorter, with the overshoot period occurring during the first several days (Klicka, 1965). Occasionally, changes in physiological makeup that occur during acclimation appear to increase, rather than counter, the problems caused by temperature change. In such a case, termed inverse acclimation, an enzyme 
may show an increase in activity due to acclimation to a higher temperature, or a decrease in activity due to temperature decrease. However, such changes can sometimes be adaptive when one considers the complexity of the systems involved. In other words, cold temperatures do not necessarily mean that the reactivity of all enzymes must increase in order to counter reduced molecular kinetic energy. An example may be found in Lagerspetz's (1971) finding of decreased acetylcholinesterase activity within the synapse in response to cold temperatures. Since it is very likely that cold inhibition of transmission is due to decreased acetylcholine activity in the synapse, a decrease in its breakdown would be compensatory. Researchers measuring other parameters expected to change during the response to high or low temperatures have sometimes found no apparent compensation to the change. otto and Rice (1974) measured a "critical speed" at which fatigue occurred in the swimming speed of Perca flavescens. Fish acclimated to $10^{\circ} \mathrm{C}$ could swim at the same speed at $20^{\circ} \mathrm{C}$, as did fish acclimated to $20^{\circ} \mathrm{C}$. There was no change in this factor over time after exposure to the new temperature. Similar results were obtained after a shift from $20^{\circ} \mathrm{C}$ to $10^{\circ} \mathrm{C}$. This could be of obvious advantage in functions that are crucial to the animal's survival, such as maximum speed.

Since air breathing poikilotherms may show almost no time lag in gravitating to the final preferred temperature (Crawshaw et al., 1980), it seems possible that something about the ventilatory medium may be of importance in the temperature selection of fish. This points to the possibility that problems of oxygen availability, potential acid-base balance 
problems or the probable changes in ion flux that would occur with any change in water flow past the gills, as potential factors in limiting water breathing animal's movements in the temperature gradient. However, Crawshaw (1984) found that decreasing the oxygen content of water in which a fish is Increasing its selected temperature toward the final preferendum does not change the rate of preference increase. It does, however, cause a considerable increase in the ventilation rate. This makes it clear that while oxygen avallability may be an energetic consideration, as the respiration of water through the gills requires considerable work, it is probably not a limiting factor in the increase of selected temperature. The $\mathrm{pH}$ of the body flulds may be modifled by many different factors, including temperature and bicarbonate level. Since $\mathrm{pH}$ is a function of the absolute concentration of protons, it is likely that $\mathrm{pH}$ changes will change the likelihood of an ionizable protein to loose or gain a proton. Since enzyme activity is dependent on Ionization, the importance of the acid/base balance is difficult to understate. In a simple model system, a bicarbonate solution in a closed system will change pH with temperature. However, the change observed is quite different than that seen in in vitro blood of constant $\mathrm{CO}_{2}$ content. Reeves (1972) showed that the addition of 20 to 50 mM Imidazole to such a solution resulted in a pH-temperature relationsh ip very similar to that of the in vitro blood. This gave rise to the term "alphastat regulation", a reference to the constant dissoclation state of the alpha proton of the imidazole portion of proteins found in all the tissues. However, it has been shown that fish allow blood $\mathrm{pH}$ to rise above expected 
alphastat values (Crawshaw et al., 1982) during temperature increase.

This may be an important cause of stress during gravitation toward the final preferendum. The proportion of $\mathrm{CO}_{2}$ in the form of bicarbonate ion is regulated largely through the action of cells in the gill epithelium which secrete bicarbonate lons to the water, probably exchanging then with chloride 1ons. There is at least some increase in tissue $\mathrm{CO}_{2}$ production as a direct result of temperature increase. However, measurements of total blood $\mathrm{CO}_{2}$ and $\mathrm{O}_{2}$ indicate that they do not change (Randall and Cameron, 1973) during temperature change. The obligate increase in oxygen uptake expected after the movement to warmer water is supported by observation of ventilation rates, which indicate an Increase in water flowing over the gill surface. It follows that the net Ion flux w1ll increase in the direction of the gradient between $\mathrm{fish}$ and environment. This process must be countered, and can be considered as another source of stress during temperature change. This Increased flow of water over the gills also leads to an Increased rate of heat gain during temperature increase. Th1s could help to explain the observation that heat gain seems to take place at a greater rate than heat loss In f1sh (Be1t1nger et al., 1977, Crawshaw, 1979). Different groups have cited electrolyte or acid-base Imbalances, edema and discuption of gill tIssues, lact 1c acid polsoning, Inact Ivation and denaturation of enzyme systems, and cardlovascular problems relating to hypoxia (Cherry and Ca1ras, 1982) as belng the cause of temperature stress in $\mathrm{flsh}$.

Prosser and Nelson (1981) concluded that nervous tissue is most significantly affected by acclimation. Th1s follows from the fact that it 
has one of the highest continuous metabolic rates of the body's tissues. It is also frequently observed that one of the first obvious problems associated with extreme temperature stress is behavioral: uncoordinated locomotion and loss of equilibrlum. The reasons for this may reside in the fallure of the electrogenic $\mathrm{Na} / \mathrm{K}$ pump or some other, membrane associated change, which are key to nervous function. Bass (1971) measured conduction velocity at a specific temperature in peripheral nerves of Ictalurus nebulosus acclimated to different temperatures and found that no temperature compensation occurred in these nerves. He measured the waveforms found over the facial lobe of the brain in response to electrical stimulation of the barbel. The wave form he saw, the "sn" wave, showed a decrease in amplitude and an increase in duration in response to cold exposure. After time for compensation at cooler temperatures, the wave form returned to that seen in warm acclimated fish. He concluded that any acclimation shown in nervous tissue function must take place at the synapse, rather than during nerve Impulse propagation along the axon. The possibility of decreased behavioral function as a result of cold temperature is of importance in the temperature gradient, particularly in those fish acclimated to low temperatures. When fish lose the ability to respond normally to temperature, death could be the rapid result.

Acclimation appears to take place at a rate described by a logarithmic function. After a sudden change of temperature, acclimation first appears to occur at a very rapld rate, then tapers off toward zero. Allen and Strawn (1971) watched the course of acclimation in Ictalurus punctatus by 
measuring the heat resistance at various times after a temperature change. This was done by placing the fish in a $40^{\circ} \mathrm{C}$ bath and measuring the survival time. They found that the acclimation process, which was completed after two to ten days, apparently started quickly, then tapered off toward completion. Hutchison's (1961) work with newts also showed an apparent logarithmic progress of acclimation. Unfortunately, his first data point was not taken until several hours after the start of the acclimation regime. If this initial high rate of acclimation is characteristic of all $\mathrm{fish}$, the measure of acute temperature preference is made more difficult, as the animal would begin to acclimate rapidly upon reaching an area of temperature choice.

Since temperature preference is measured statistically, the more time, or data points one can use to measure it, the more accurately it can be described. In order to measure the acute temperature preference, individual fish can only be watched for a short time, so large numbers of fish are needed in order to give reliable results. Reynolds and Casterlin (1979) recommend that the acute temperature be measured within the first two hours out of the acclimation temperature, and even within that time, some movement toward the final preferendum may take place.

Muller and Fry (1976) determined the final preferendum of Lepomis by the method of plotting acute preferred temperature against the acclimation temperature. The intersection of this line and the line indicating equal preferred and acclimation temperatures is considered to be the final preferendum. They measured the acute temperature preference by first 
allowing the flsh to stay in a temperature gradient for 40 to 120 minutes, then measuring the body temperature with a thermocouple. Shingleton et al. (1981) determined the final preferendum of Notropis scabriceps using a similar method. The acclimation regime used in this experiment involved only 5 days stay at the acclimation temperature, after a slow $\left(<1.0^{\circ} \mathrm{C} /\right.$ day $)$ change from holding conditions. Their measure of acute preferred temperature was made by introducing the fish to a gradient tank at the level equal to the acclimation temperature. The fish were then allowed 40 minutes to explore and adjust to the tank. The preference was then determined during the next 20 minutes, using observations made at 15 second intervals.

Researchers have used many methods and terms to determine and define the status of animal thermal adjustments. The tolerance of $\mathrm{fish}$ to heat extremes is one such measure and the ability to respond in an adaptive manner is another. The tolerance zone, a concept described by Fry and Hart in 1947, is the range of temperatures in which a fish might be found. This area can be graphically demonstrated using temperature and acclimation temperature as the axes (FIg. 1). The area outside these lines is called the resistance zone, an area to which an animal might shuttle briefly during feeding or escape behavior, but not stay in. The area encompassed is a measure of the thermal capabilities of a particular species. While the fish is always found within the bounds of this polygon, the likelyhood that it will be in any given location is largely determined by the animal's thermal history, or acclimation state. The CTM, or critical thermal maximum, is defined by a 
Ine outside the resistance zone and represents an area in which death is almost 1ramediate. Some researchers test the acclimation state of their animals by 1ncreasing the temperature unt1l obvlous behavloral defects occur, of ten the loss of equilibriur. Allen's previously cited work with Ictalurus utflized a similar method. However, vartables, such as the rate of temperature increase and the behaviocal criterla used, are often approached by researchers using different methodologies, thus it may be difflcult to compare results.

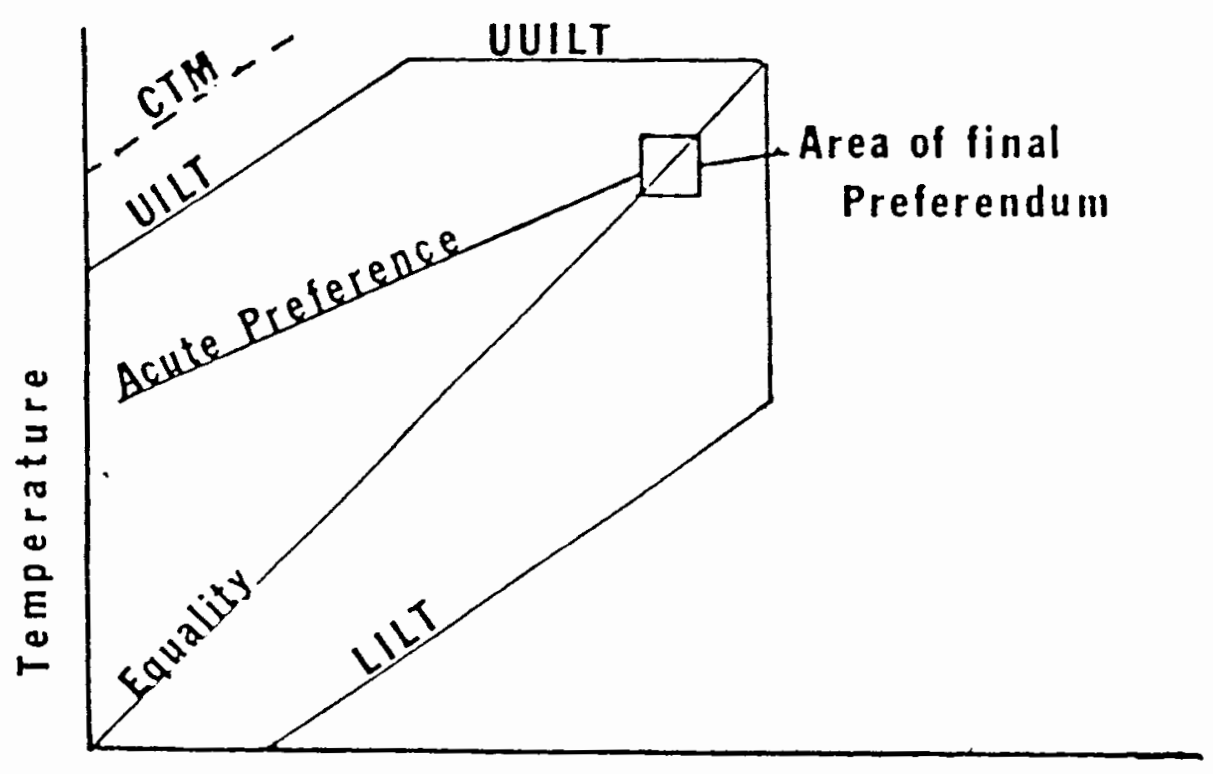

Acclimation Temperature

F1gure 1. Example of tolerance zone (from Jobling, 1981). CTM, Critical Thermal Maximum; UILT, Upper Inclplent Lethal Temperature; UUILT, Ult Imate Upper Inciplent Lethal Temperature; LILT, Lower Inclplent Lethal Temperature.

It is belleved that this ablilty to sense and select a specific temperature is based largely in an area of the hypothalamus found in all vertebrates called the preoptic nucleus (Sat 1noff, 1974). This area is 
belleved to have input from various peripheral sensors, along with a reference source against which the varying input from the peripheral receptors is compared. A lesion in this area of Lepomis cyanellus and Carassius auratus brains causes a loss of the ability to behaviorally thermoregulate (Nelson and Prosser, 1979). Crawshaw and Hammel (1974) implanted thermodes in various areas of the brains of Ictalurus nebulosus and found that heating or cooling of the anterior brainstem, close to the hypothalamus, had the greatest effect on temperature selection. Kavalier's (1982) work with Catostomus commerson 1 showed that temperature preference may also involve other areas of the brain. Pinealectomy caused a decrease in the normal dafly varlation of temperature preference and a general increase in the overall selected temperature of summer fish. Winter fish, however, showed fewer changes after pinealectomy. Because of the multiple interactions of the hormones and their effectors, it is not surprising to find that changes of such a complex expression as body temperature would be affected by removal of the pineal, a secretor of melatonin.

Previous temperature experience is not the only parameter that can Influence preferred temperature. For instance, photoperiod, soclal interactions, salinity, age, pyrogens (bacterial or chemical) and nutrition may all affect the behavior of fish in a gradient. The term acclimatization describes the process of adjusting to temperature changes in a natural setting, where numerous environmental factors may affect thermal compensatory responses. Also of great 1mportance in determining an an1mal's response in a temperature gradient, is the temporal distribution of these factors. For 
example, temperature selection can be affected by the range and period of temperature fluctuations that an animal is subject to during the acclimation period. Heath (1963) acclimated Salmo clarki temperature cycles of varying periods. Changes in the critical thermal maxima of the fish subsequently occurred, with the fish on the 24 hour cycle showing the greatest tolerance to high temperature. Fish on the 24 hour period, cycled between 10 and $20^{\circ} \mathrm{C}$, showed the same tolerance as those that had been acclimated to a constant $20^{\circ} \mathrm{C}$. Thus, fish seem to adjust their tolerance to the extremes that they encounter. This was most effectively done when the extremes were found on a 24 hour period, as they probably would be in nature. The time of the environmental temperature maximum is apparently important to the general metabolism of the animal. Carassius auratus, when exposed to a daily temperature maximum early in the day showed an enhanced rate of weight gain over those with maxima at other times of the day (Spieler and Noeske, 1977).

A diel, or daily pattern of temperature tolerance is found in Bulger's work (1984) with Fundulus heteroclitus. This would be of functional significance in the thermally labile environment of this estuarine fish. Similarly, Reynolds et al. (1978a) found that Carassius auratus has a diurnal pattern of temperature preference. This pattern coincided with one found to cause maximal growth in fish living in experimental temperature regimes. Activity was also high during the period of high temperature selection, possibly indicating an active search for the preferred temperature. This idea was further supported by Brett (1971) who had 
observed the diel vertical migration habits of Oncorhynchus nerka. The fish spent much of their time on the cold bottom, rising only to feed at dawn and dusk. In their environment, which was believed not to have enough prey to satiate the young salmon, this was seen as a behavioral control of energet ic output. Reynolds et a1. (1978b) found that the bowfin, Amia calva, showed a strong circadian temperature cycle. Although the data showed that they preferred a warm day temperature, they showed no sign of a diel locomotor rhythm. However, most reports of activity patterns show a circadian cycle, while not all fish show circadian temperature cycles. Beltinger (1975) found no evidence of thermal preference cycles in Lepomis, and Reynolds and Casterlin (1978) found that Catostomus maintained a constant body temperature without dally fluctuation, although they exhibited clear nocturnal activity patterns. It seems quite likely that circadian temperature cycles, when they exist, could be a result of energetic considerations.

Besides the diel patterns, fish have also been shown to have a circannual pattern of preferred temerature. Sullivan and Fisher (1953) found that Salvelinus fontinalis showed a sudden decrease in temperature selection in December, and a similar increase in March. These changes could not be explained by the temperature of the holding tanks, which changed only slightly, and at a slow rate. This pattern may be adaptively synchronized with the season through cues, such as photoperiod. Kowalski (1978) controlled this varlable in acclimating minnows to $15^{\circ} \mathrm{C}$ under a $\mathrm{LD} 12: 12$ reglme. These fish showed critical thermal maxima that were higher in March 
than in mid-winter.

Another clear influence on fish behavior is the effect of starvation. Spieler and Noeske (1984) observed the activity of starved Carassius auratus. These fish tended to loose their circadian rhythmicity. However, any outside indications of the circadian period, such as a daily feeding schedule, could result in entrainment and resumption of diel rhythms. It seems likely that loss of the circadian cycle would change the temperature preference of such animals as they try to maintain the activity levels necessary for food searching, while rationing their dwindling reserves.

A related aspect of temperature change and acclimation is discussed by Hutchison and Maness (1979). Brief exposure to high temperatures near the lethal level during acclimation results in an increased tolerance to subsequent high temperatures. The difference between this temperature "harden Ing" and acclimation appears to be in the time course of the change. Similarly, Hutchison (1961) found that newts exposed to a lethal temperature for a very short period of time, then returned to their previous acclimation temperature for varying perlods of time showed a hardening effect with an increased critical thermal maximum. This effect disappeared after several hours. The time span for this phenomenon is considerably shorter than has been described for the process of acclimation. Another apparent difference is found in the necessity for the exposure temperature to be in the near lethal range. Also, the process of hardening is apparently quantal: there is a single defined plateau to the response, and no further hardening occurs after the first exposure to the lethal temperature. 
Thus a measure of acute temperature preference is made difficult by a number of factors. Diel and annual temperature patterns can be compensated for by treating and testing all fish at the same time of year and day. Feeding must be at a consistent time of day and sufficient to cover the normal needs of the animal. Although it would be difficult to know if any of the $\mathrm{f}$ ish were under the influence of endogenous or external pyrogens, the possiblity must not be overlooked. The amount of time that fish are given to choose a temperature is also of clear importance. The fish must be allowed enough time to settle down from handling and to explore their new environment, yet not so much time that the acclimation process begins in the gradient, affecting the acute preferred temperature. As previously mentioned, as large a number of $\mathrm{fish}$ as possible must be used in order to obtain reliable results.

Since much of the literature about the process of acclimation is subject to conflicting results and speculation, it is clear that the subject needs further study. In this study, I researched the subject by finding the acute preferred temperature of $\mathrm{fish}$ after acclimation to various regimes. Fish were also observed during the period of temperature preference increase toward the final preferendum. While direct evidence of physiological processes were not discernable with this method, it is possible they may be inferred from aspects of temperature selection behavior. Ideas and tests can then be based on further knowledge of the dynamic and multifaceted process of acclimation. 
CHAPTER II

\section{MATERIALS AND METHODS}

Two procedural methods were used to observe the process of acclimation. First the procedure used for the Goldfish (Carassius auratus) will be described, followed by that used for the Brown Bullhead (Ictalurus nebulosus).

I. Carassius used in the experiment had been kept in an outdoor pool for at least one year. A11 fish used, randomly chosen from the holding pool, were 5 to $8 \mathrm{~cm}$ long. Five acclimation tanks of about 40 gallons were set up in a greenhouse. Water was filtered with large capacity aquarium filters. All tanks were initially kept at the ambient temperature of the greenhouse, which fluctuated somewhat, but centered around $25^{\circ} \mathrm{C}$. A total of 124 fish were distributed in the tanks, which were then stabilized at approximately $23^{\circ} \mathrm{C}$ over the next three days. Fish were then redistributed among the five tanks as follows: $29 \mathrm{fish}$ each were placed in the tanks designated for $3^{\circ} \mathrm{C}$ and for $8^{\circ} \mathrm{C}, 28 \mathrm{fish}$ each in the tanks designated for $13^{\circ} \mathrm{C}$ and for $18^{\circ} \mathrm{C}$, and $10 \mathrm{fish}$ were placed in the tank to remain at $23^{\circ} \mathrm{C}$. Two days later, $9 \mathrm{fish}$ each were netted from the tanks designated to 3 and $8^{\circ} \mathrm{C}$ and used in a determination of the acute preferred temperature through two runs in the temperature gradient tank. The escape behaviors usually elicited by the presence of the net during fish capture helped to decrease bias during 
subject selection. The procedure used to determine the preferred temperature will be described shortly. The day of this first run was considered as the starting point of the acclimation regime, during which the temperature of the tanks was slowly lowered to the designated level. The objective was to lower the temperature at a rate of $1.5^{\circ} \mathrm{C}$ per day, since a sudden change to the lower acclimation temperatures from the holding tank conditions could be deleterious or even lethal.

A total of fourteen runs were performed, five of which utilized fish that had been held for up to 51 days at the lowest temperature, $3^{\circ} \mathrm{C}$. Runs are identifled by two numbers, the first describing the temperature of water from which the fish were taken, and the second indicating the number of days the fish had spent in the acclimation regime. Thus the two runs performed on day one w111 be referred to as runs 23-1A and 23-1B. Other runs were as follows: $23-18,18-7,18-20,13-11,13-33,8-17,8-34,3-23,3-32,3-38$, 3-52, and 3-74.

In all acclimation tanks, fish were fed until satlation. Those fish in the warm temperatures ate considerably more than those at the low temperatures, which only needed to be fed once a day. The temperatures of the tanks, checked two or three times a day during the period of change, did not decline evenly, and occasionally, steep declines and increases occurred during the experimental acclimation regime. One run had to be redone due to technical problems, and a redistribution of fish between tanks of equal temperature was required to leave enough $\mathrm{fish}$ in the lower temperature tanks. The appendix details acclimation regime temperatures and indicates the time 
and the origin of the $\mathrm{f}$ ish used in the runs.

Acute temperature preference was determined using the following procedure. Nine fish were placed together in one lane of the temperature gradient tank for 15 minutes to gain experience in the situation. They were then moved to separate lanes of the gradient, where individuals were allowed to move freely for about thirty minutes. Fish were not reused during the experiment. The temperature gradient tank consisted of an open-topped box divided into nine separate lanes. Each lane was about $240 \mathrm{~cm}$ long, $20 \mathrm{~cm}$ wide and $9.5 \mathrm{~cm}$ deep. At one end of each lane, heat exchangers were coupled to a hot bath, while at the other, heat exchangers were coupled to a cold bath. Each lane was partially divided by baffles into 10 equally sized compartments. These compartments were aerated to prevent vertical or horizontal stratification of temperature. This system maintained a relatively stable and even thermal gradient. Cont inuous monitoring showed variations of not more than $0.5^{\circ} \mathrm{C}$ within the lanes during an experiment. A complete temperature profile of each lane was made at the end of the experiment by measuring the temperature at the center of each compartment. Later these figures were used to calculate preferred temperature from the recorded data describing fish position in the gradient. The minimum gradient temperature was set to a temperature a bit lower than the acclimation temperature. Shrouds were used to reduce the outside influences of light and movement which could affect $\mathrm{f}$ ish behavior. The aerators along the length of the gradient helped to mask sound or vibrational disturbances. Observations were made with a Panasonic WV-1854 high resolution televison camera with a 
wide angle lens. Fish position in the gradient was compiled at six second intervals by a software program executed by an IBM PC XT computer equipped with a frame grabber. A binary file recorded information defining fish position during the experiment on an IBM $10 \mathrm{Mb}$ hard disk. This information could be accessed, converted to temperature with the callbration figures measured from the gradient, and printed out or analyzed. A continuous record of fish position in the gradient at each six second interval was printed by an Epson LQ-1500 dot matrix printer. In this experiment, the six second observation points were averaged over two minute periods, and a printout of these values was produced. Since the norm of behavior involved considerable movement through the gradient, clearly seen on the record of $\mathrm{fish}$ position, and just after handling, fish activity frequently stopped, temperature preference data was utilized only for the final 20 minutes in the gradient.

II. Ictalurus were collected from a private pond near Sandy, Oregon on the third and fourth of August, 1984. The surface temperature was approximately $18-19^{\circ} \mathrm{C}$ at the time of capture. For this experiment, which was designed to examine both the acute temperature preference and at least part of the return to the final preferendum, the fish used were approximately $14-18 \mathrm{~cm}$ long. They were placed in a holding tank at $24^{\circ} \mathrm{C}$ until August 9. At that time, the first group of fish was selected in the fashion described for Carassius, and used in a determination of the acute preferred temperature and to observe the return to the final preferendum of temperature choice. The nine fish used in this run, termed 24-1, were placed in individual lanes 
of the temperature gradient, prevlously described, and allowed to move freely. All subsequent runs ut1l1zed only $s 1 x$ f1sh. Run 15-2 was taken from the holding conditions approximately 24 hours after the temperature had been lowered. These fish were left in the gradient for fifty minutes. Aga1n, the temperature of the holding tank was lowered to $7^{\circ} \mathrm{C}$ after removal of $15-2$ fish. One day later, fish for run 7-3 were removed and allowed to stay In the gradient for ninety minutes. After treatment $2 \mathrm{flsh}$ were removed, the holding tank temperature was lowered to the lowest temperature to be tested, $3^{\circ} \mathrm{C}$. Runs $3-4,3-5,3-6$, and $3-7$ were performed over the next 4 days. Since these fish took longer to approach the fInal preferendum, the stays in the gradient were longer, Involving stays of 90 and 260 minutes for runs 3-4 and $3-5$, and $680 \mathrm{minutes}$ for runs $3-6$ and $3-7$.

Act Ivity was recorded on tape with the ald of a video camera. An observer entered fish position into a computer flle at flve second intervals while watching a replay of $\mathrm{f}$ Ish behavior on a monitor. These data points were then converted to temperature values using callbrat lons obtained in the procedure previously described. These were averaged over five minute periods for runs $24-1,15-1,7-1$ and $3-1$, whlle 1 n runs $3-2,3-3$ and $3-4$, data points were averaged over ten minute perlods. Standard error estimates were calculated by the computer for each of the time perlods, and a rough measure of activity was calculated for each Interval by summing the absolute value of the change of position in the gradient at each five second Interval. 
CHAPTER III

RESULTS

The most typical behavior of Carassius in the gradient consisted of wide ranging movements within a defined portion of the gradient, along with occasional forays into both the coldest and the warmest portions. This behavior started between 0 and 20 minutes after fish were placed in the Individual lanes of the gradient. Some fish did not range nearly so far, remaining within a restricted area of the gradient, yet maintaining mobility. Other fish showed a random distribution of points on the printout of fish position in the gradient, indicating much back and forth movement through the length of the gradient.

Table I indicates the average from each lane for all runs, along with the grand mean and standard error of each run. Analysis of variance (Table II) of the data Indicated that significant differences existed between the group means. Although Bartlett's test of homogene1ty of variance Indicated considerable difference between the group variances, decreasing the validity of comparisons between runs, Zar (1984) indicates that the analysis of varfence works well, even under such conditions of heterogeneity of variance. Thus, it is probable that the null hypothesis, that there is no difference between the group means, can be discarded. The Student-Newman-Keuls test was used to determine the significance of differences between groups. 


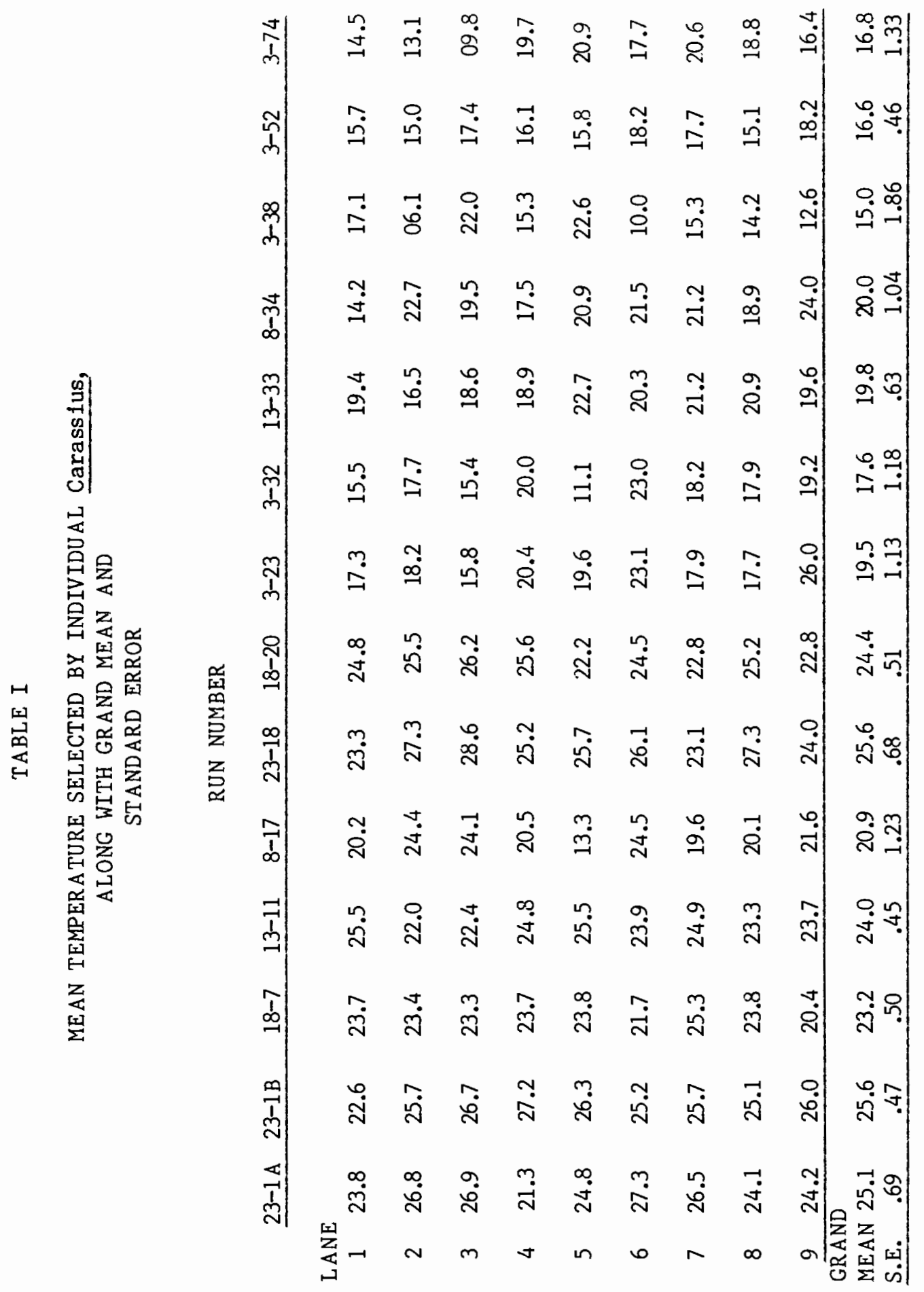


A non-parametric test, the Kruskal-Wallis was performed on the data. This test too, indicated a significant difference between groups. Several histograms of temperature selection in individual fish were performed, and a representative histogram (F1gure 2, graph A) shows the previously described negative temperature skew, indicating that more time is spent in a relatively lower portion of the temperature range than in higher portions. In some

TABLE II

RESULTS OF ANALYSIS OF VARIANCE ON Carassius DATA

ANOVA: $\quad F(13,112)=16.3 ; p<.01$

Bartlett's test of Homogene1ty: Ch1-square (13) $=45 ; \mathrm{p}<.005$

Source of Variance:

Within groups $37 \%$

Between groups $63 \%$

NON-PARAMETRIC TEST

Kruskal-Wallis: $\quad$ H $(9,9,9,9,9,9,9,9,9,9,9,9,9,9)=293 ; \quad$ p.001

Significant differences ( $p .05$ ) indicated by Student-Newman-Keuls procedure:

3-38 vs. $3-23,13-33,8-34,8-17,18-7,13-11,18-20,23-1 \mathrm{~A}, 23-1 \mathrm{~B}, 23-18$

3-52 vs. $8-17,18-7,13-11,18-20,23-1 \mathrm{~A}, 23-1 \mathrm{~B}, 23-18$

$3-74$ vs. $18-7,13-11,18-20,23-1 \mathrm{~A}, 23-1 \mathrm{~B}, 23-18$

$3-32$ vs. $18-7,13-11,18-20,23-1 \mathrm{~A}, 23-1 \mathrm{~B}, 23-18$

$3-23$ vs. $13-11,18-20,23-1 \mathrm{~A}, 23-1 \mathrm{~B}, 23-18$

13-33 vs. $13-11,18-20,23-1 \mathrm{~A}, 23-1 \mathrm{~B}, 23-18$

8-34 vs. $18-20,23-1 \mathrm{~A}, 23-1 \mathrm{~B}, 23-18$

8-17 vs. $23-1 \mathrm{~A}, 23-1 \mathrm{~B}, 23-18$ 


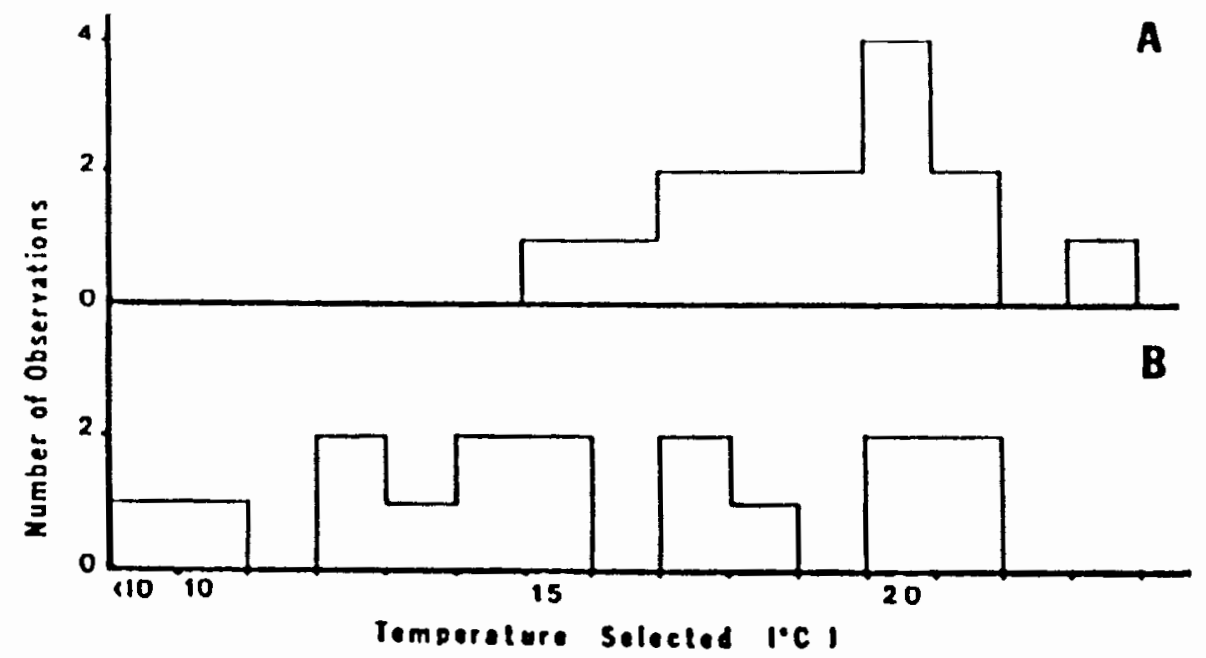

Figure 2. Histograms of temperature selection for individual Carassius in gradient ( $A$; run $13-11$, lane $7, B$; run $3-74$, lane 8 ).

cases, it is clear that the limits of the temperature gradient are responsible for the appearance of skewness, with some $f$ ish not moving from the vicinity of the heat exchangers. In several individual nuns, the average temperature selected over periods of 5 to 20 minutes was near the highest temperature in the gradient, as indicated by the calibrations. Although not conclusive, the behavior of these $\mathrm{f}$ ish indicates that $\mathrm{fish}$ temperature selection is affected by limited gradient temperatures.

Some fish showed very little tendency to move about in the gradient. This was genera1ly more noticeable in the fish acclimated to the cold temperatures. It was most apparent in run 3-38, where all $\mathrm{f}$ ish remained quiescent for extended periods of time. However, even after 14 days at the warm acclimation temperature of $23^{\circ} \mathrm{C}$, one $\mathrm{f}$ ish in the gradient moved to a position just above $27^{\circ} \mathrm{C}$ and remained almost motlonless for the thirty minutes of the run. At the other extreme, some fish showed a broader distribution of selected temperatures with no clear mode, displaying little 
precision in thermoregulation, as seen in Figure 2, part B.

Carassius acute temperature preferences showed a clear dependence on temperature of acclimation. Iinear regression of average selected temperature in each lane versus acclimation temperature showed a significant portion of the varlance in temperature choice was explained by the regression Iine $\left(\mathrm{df}=1,125, \mathrm{~F}=160, \mathrm{p} \times .001, \mathrm{r}^{2}=.56\right)$. F 1gure 3 shows the preferred temperature plotted agalnst the acclimation temperature, along wth the

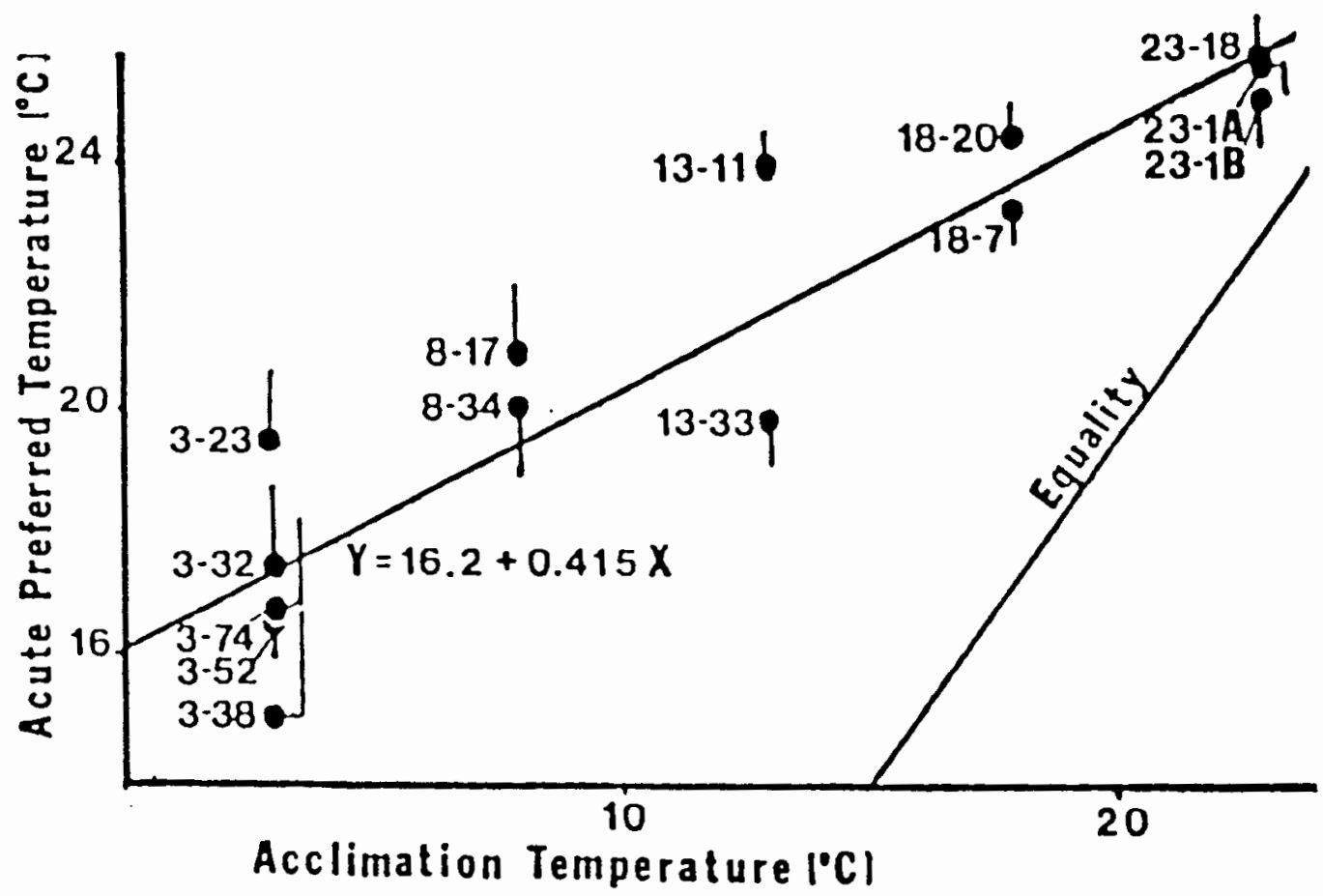

Figure 3. Changes in Carassius' acute preferred temperature with acclimation temperature (run numbers and standard error indicated).

regresssion 1 ine described above. Since the acclimation regime involved a steady temperature decrease from the initial holding temperature of $24^{\circ} \mathrm{C}$, a good quantitative measure of thermal history could be defined as the amount 
of time spent in the decreasing temperature regimes. When this is plotted against acute temperature preference (Figure 4), a 11near relationship is seen $\left(\mathrm{df}=1,53, \mathrm{~F}=43, \mathrm{p} \times .001, \mathrm{r}^{2}=.45\right)$. As can be seen, the decrease In preferred temperature does not match the rate at which the acclimation regime temperature decreased. Data from runs $3-32$ and $3-38$ is also plotted. Although the temperature of the acclimation regime is no longer dropping, they show that temperature preference continues to drop at the nearly linear rate for at least 15 days after the temperature stab111zed at $3^{\circ} \mathrm{C}$.

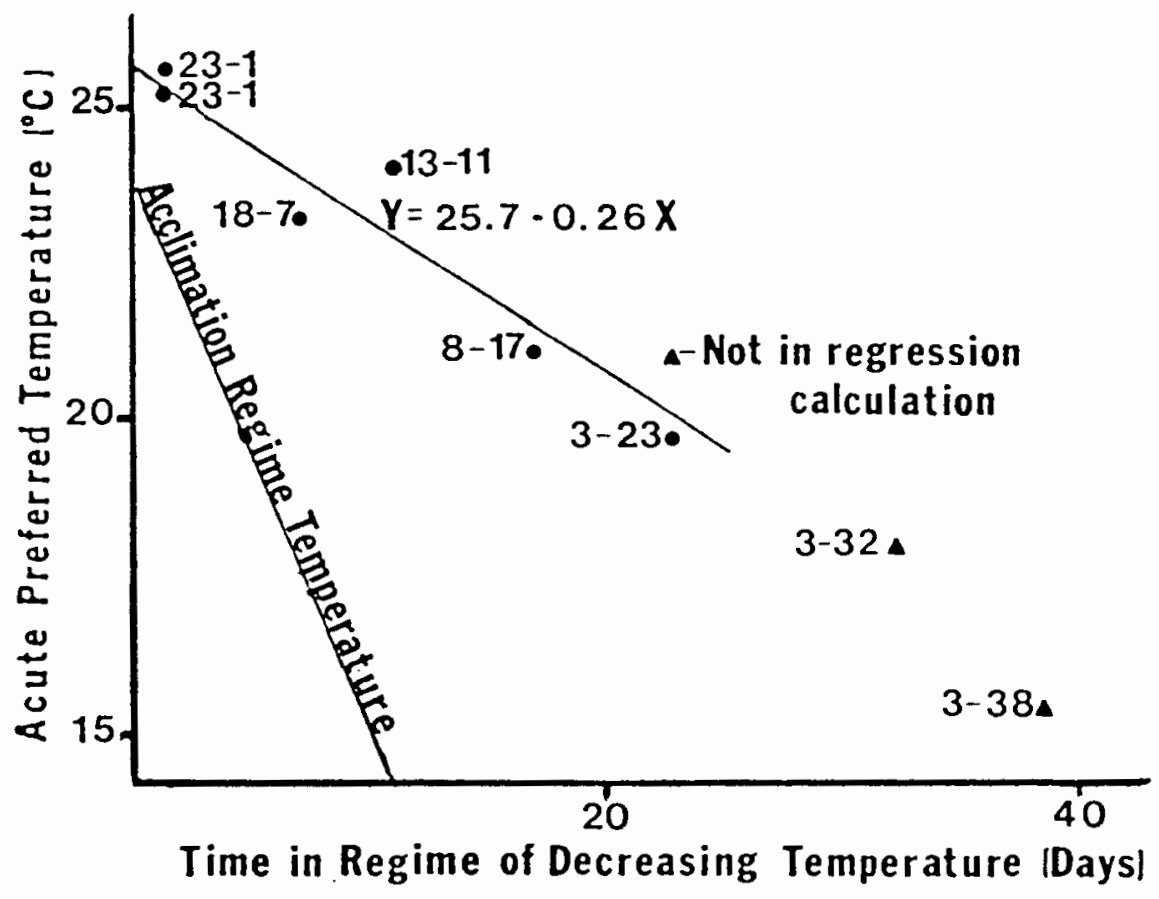

Figure 4. Effect of time in acclimation regime on Carassius acute temperature selection.

In all cases, except for the $18^{\circ} \mathrm{C}$ data, temperature preference decreased further after reaching the acclimation temperature. However, the $\mathrm{f}$ ish acclimated at $3^{\circ} \mathrm{C}$ for extended periods of time were not consistent 
with this trend. The first three observations showed a decrease in preference over the first 15 days, significant $(p<.05)$ by the StudentNewman-Keuls test (Table II). This trend then stopped, with the next 36 days showing no apparent decrease in $\mathrm{f}$ ish temperature preferences. The Student-Newman-Keuls, a fairly conservative test of mean differences, does not show any significant differences between means through this time period. Figure 5 shows the relationship found between time spent at $3^{\circ} \mathrm{C}$ and the acute temperature preference.

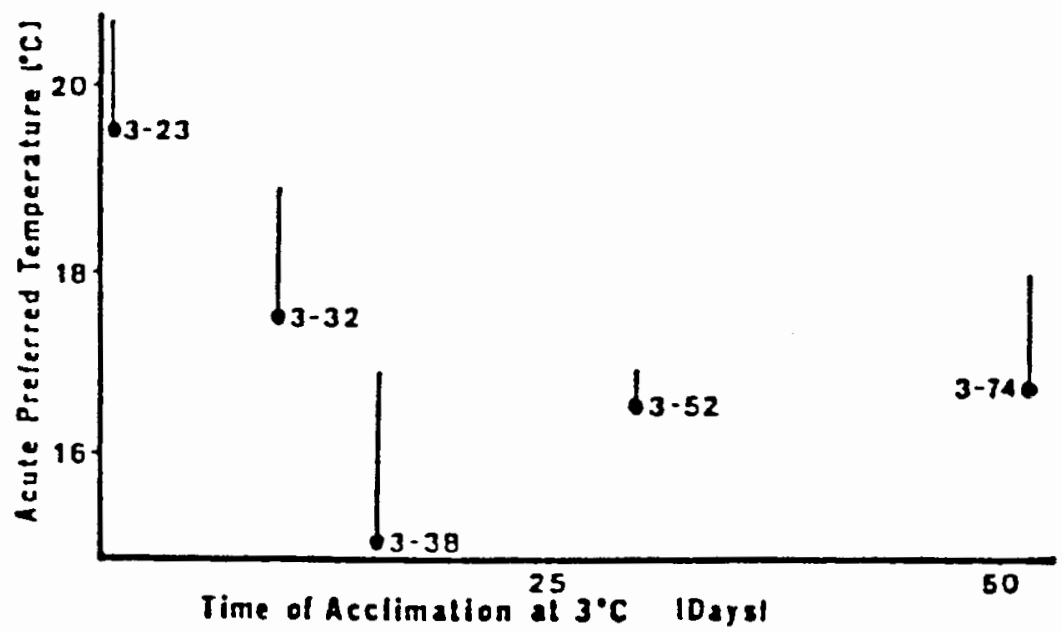

Figure 5. Carass 1 Cus $^{-}$acute preferred temperature during $3^{\circ} \mathrm{C}$ acclimation (mean of run and standard error).

The overall behavior of Ictalurus in the gradient was quite similar. Upon placement in the gradient at the level of the acclimation temperature, the fish immediately moved to locations indicating a dramatic increase in preferred temperature. This initial temperature jump was usually followed by 
a perlod during which little upward movement of selected temperature occurred (although downward movement did occur). Following this lapse, there was a rapid increase in temperature selected toward the final preferendum.

Figure 6 shows the relationship between previous thermal experience and the temperature chosen over the first twenty minutes, the period during which the fish showed little tendency to increase their temperature choice. Time spent at $3^{\circ} \mathrm{C}$ is a significant determinant of choice during the first twenty minutes $\left(\mathrm{df}=1,9, \mathrm{~F}=58, \mathrm{p}<.001, \mathrm{r}^{2}=.88 ;\right.$ see Figure 7$)$.

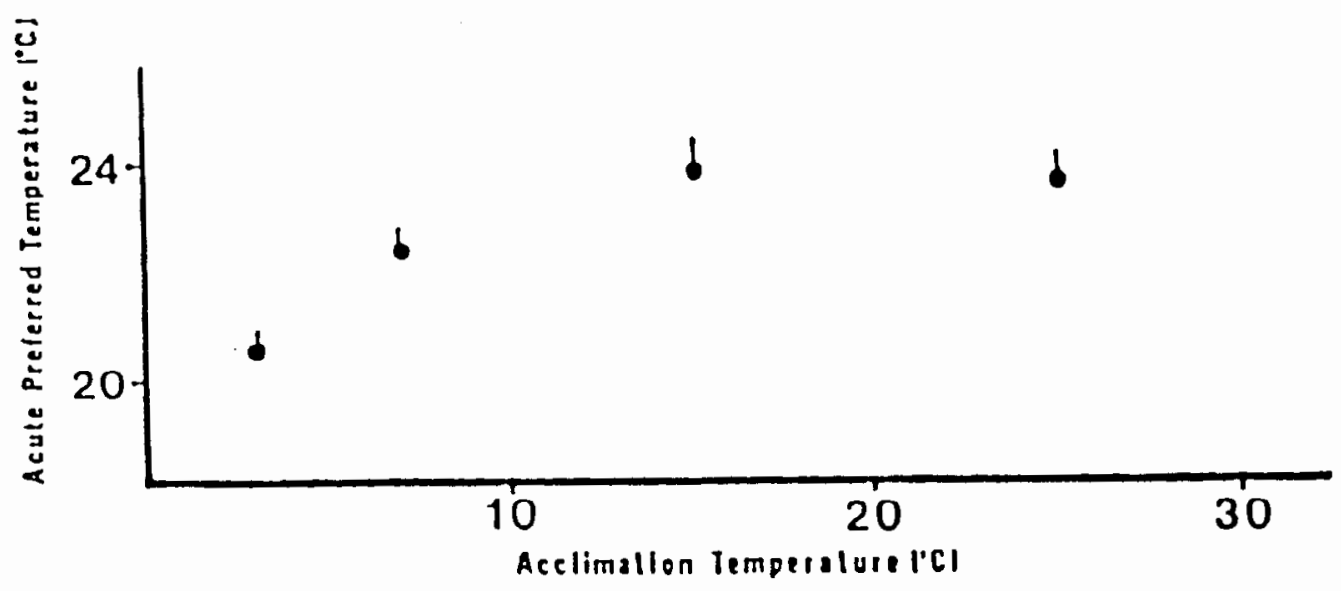

Figure 6. Acute preferred temperature of Ictalurus after 24 hours at various acclimation temperatures (mean of run and standard error).

Figure 8 shows temperature selection averages for the runs. It is clear that acclimation was in process during the four days at $3^{\circ} \mathrm{C}$, since obvious differences are seen in the fishes' return toward final preferendum temperatures. One difference is seen in the time taken for the fish to reach an intermediate temperature of $25^{\circ} \mathrm{C}$, which was used as a reference to note the rate of increase of selected temperature since not all the runs 


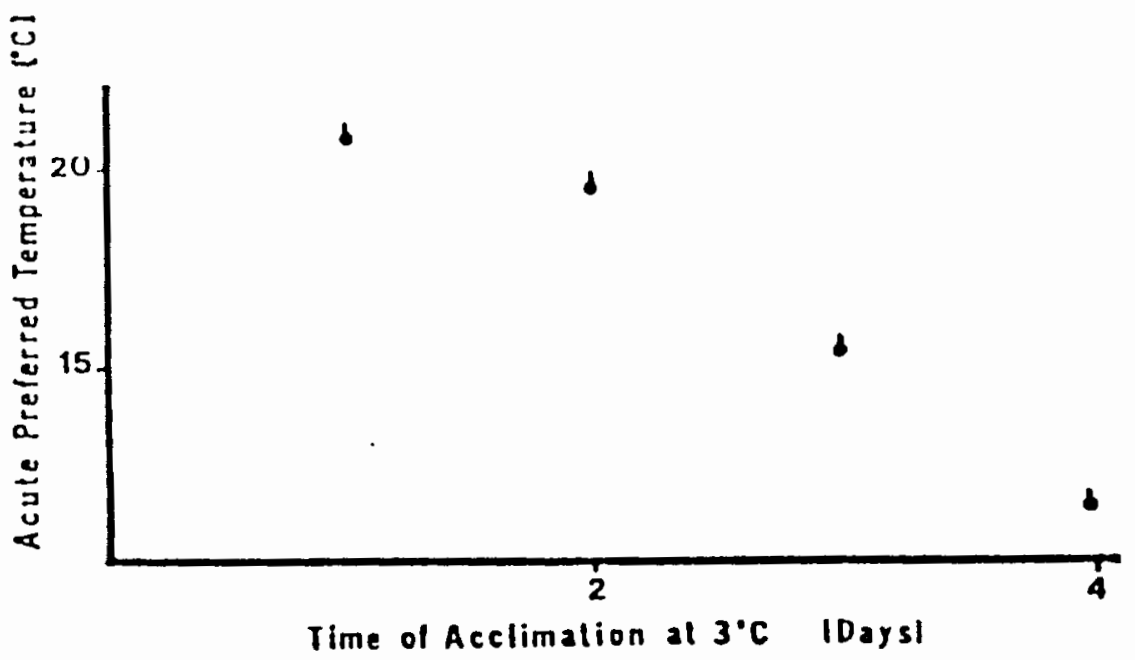

Figure 7. Acute preferred temperature of Ictalurus after various times at $3^{\circ} \mathrm{C}$ (mean of run and standard error).

attained final preferendum temperatures. As was seen in the Carassius data, increasing the acclimation time at low temperatures results in more profound effects on temperature preference. Figure 9 shows the effect of 4 days acclimation time over that of 1,2 or 3 days at $3^{\circ} \mathrm{C}$ in the time required to reach the reference temperature. The difference between 4 days and 1,2 and 3 days is significant $(\mathrm{df}=2, t=11.67, \mathrm{p}<.005)$. If one looks at time taken to reach $25^{\circ} \mathrm{C}$ versus acclimation temperature (Figure 10), a more linear relationship is seen, although the slope is steepest at lower acclimation temperatures.

The period after the initial temperature fump, during which 1ittle change in preferred temperature occurred, is also affected by the acclimation history. The effect is significant when correlated with time spent at $3^{\circ} \mathrm{C}$ (p<.05; see Table III). During this perlod of 11ttle or no increase in 


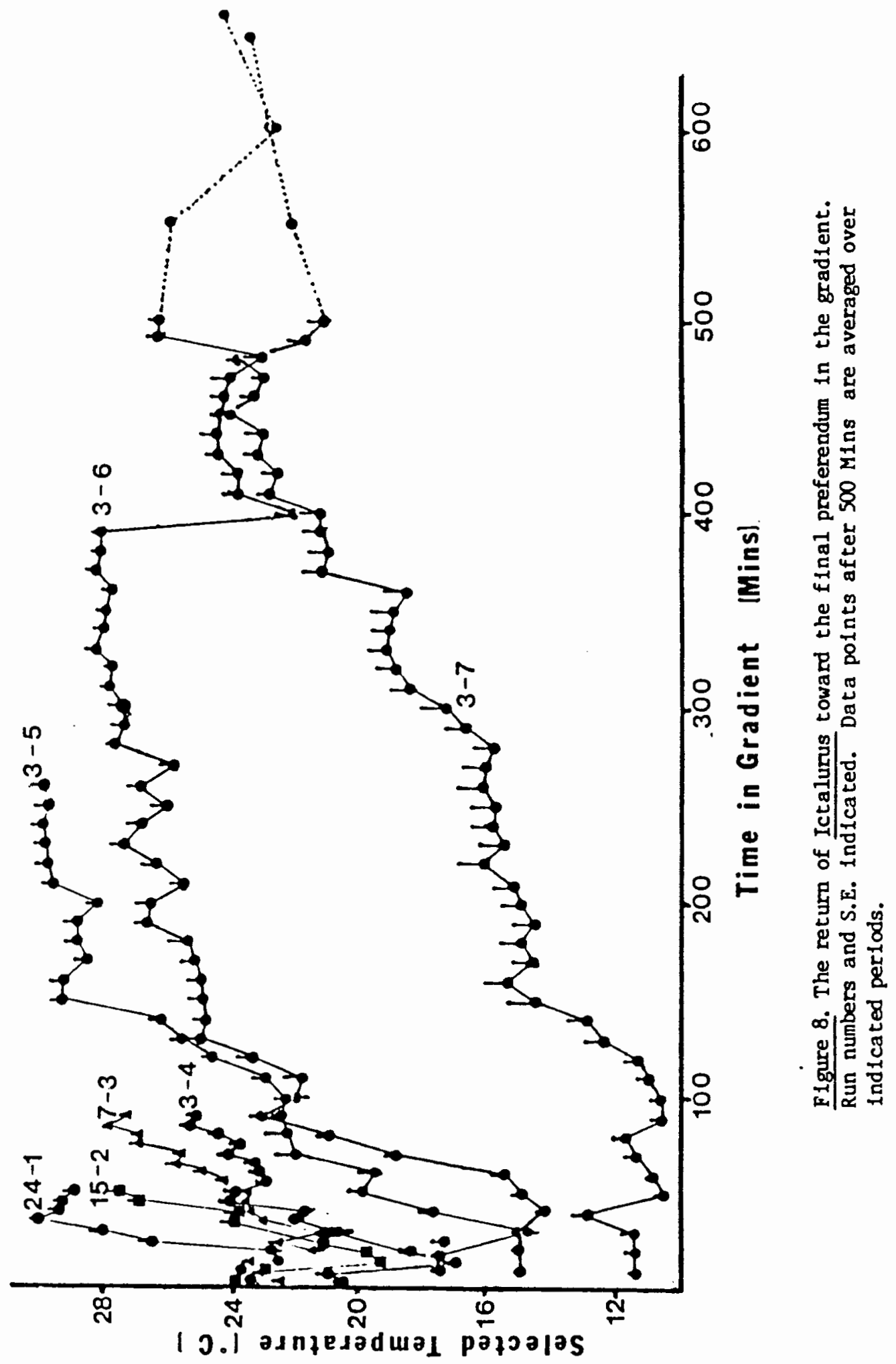




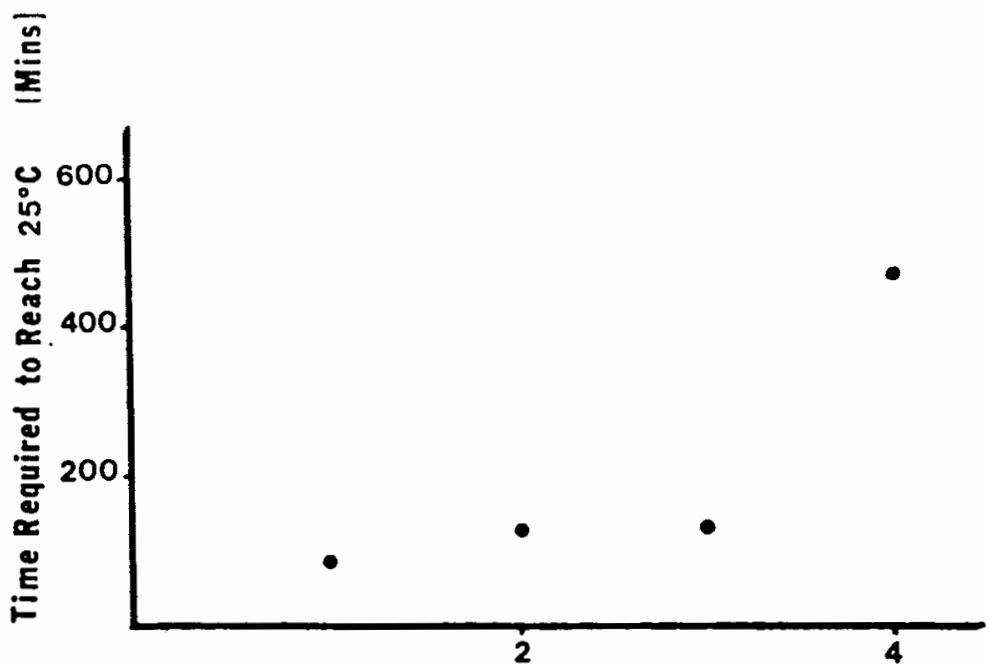

Time of Acclimation at $3^{\circ} \mathrm{C} \quad \mid 0 \mathrm{ays}$

Figure 9. The effect of $3^{\circ} \mathrm{C}$ acclimation on Ictalurus return toward the final preferendum.

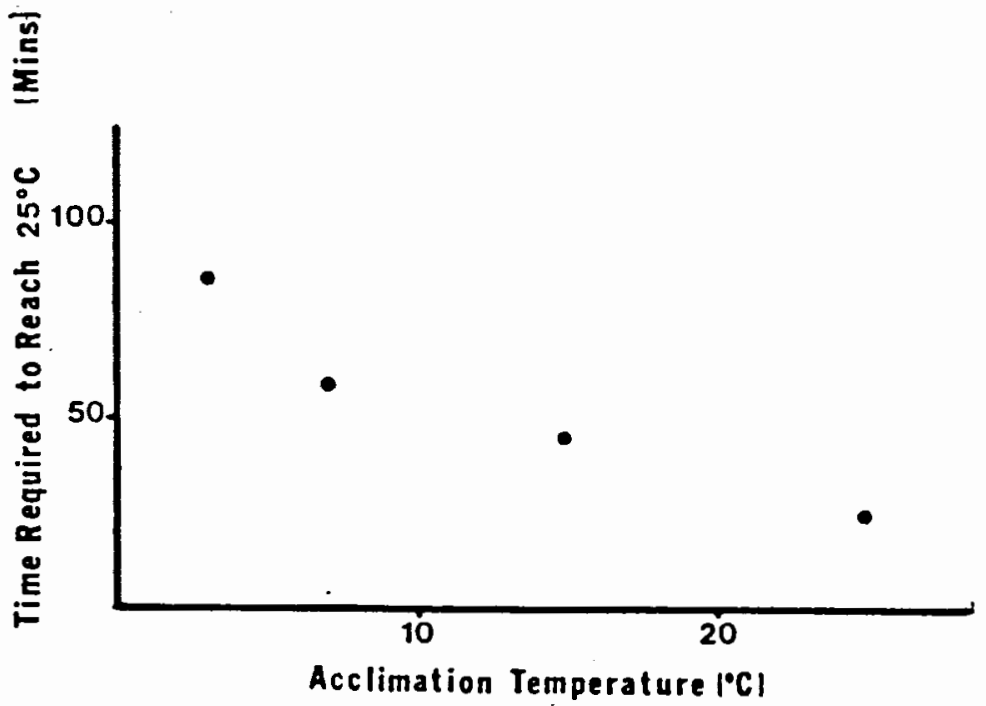

F1gure 10. The effect of acclimation temperature on Ictalurus' return toward the final preferendum. 
selected temperature, fish appeared to be more active than during the remainder of the run, except in the fish that had been held at $3^{\circ} \mathrm{C}$ for more than a day. These fish showed very low levels of activity throughout the time in the gradient. However, significant activity differences during the course of the run, as determined by the Student's $t$ test, were found only in run 15-2. Not surprisingly, higher standard errors were also found during the period before the rapid increase in selected temperature, except in those fish that had spent time at $3^{\circ} \mathrm{C}$. Table IV details the significance of standard error and activity differences for each run, and indicates the time periods involved.

At various points in time, the $f$ ish began their rapid increase in selected temperature. As can be seen from the line slopes in Figure 8, all of the runs showed at least brief periods of increases in the neighborhood of $0.25^{\circ} \mathrm{C} / \mathrm{minute}$. The fish acclimated to warmer temperatures managed temperature increase rates of almost $0.6^{\circ} \mathrm{C} / \mathrm{minute}$. In runs $24-1,15-2$, 7-3 and $3-5$, this increase brought the fish to a point near the final preferendum, reported variously at $27-31^{\circ} \mathrm{C}$ in a review by Reynolds (1977). Fish acclimated at $3^{\circ} \mathrm{C}$ for less than two days moved toward their final preferendum without substantially altering this steep rate of increase. Although run 3-4 was not continued long enough to reach this point, it was apparently on a similar course to runs $24-1,15-2$ and $7-3$. However, after spending more time at $3^{\circ} \mathrm{C}$, the fish were not able to maintain the steep increase. The fish in run 3-6, which ultimately reached final preferendum temperatures, acted typically in their temperature selection patterns. After 
TABLE III

LATENCY OF TEMPERATURE SELECTION INCREASE

IN Ictalurus

TREATMENT NUMBER

DAYS AT $3^{\circ} \mathrm{C}$

LATENCY OF SELECTED

TEMPER ATURE INCREASE

(X)

(Y)

\begin{tabular}{ccc}
\hline 3 & 1 & 30 Minutes \\
4 & 2 & 40 \\
5 & 3 & 60 \\
6 & 4 & 120 \\
\hline$Y=-10.3+29 X ; r^{2}=.86 ; F(1,3)=12.6 ; p<.05$ \\
\hline
\end{tabular}

TABLE IV

CHANGE IN STANDARD ERROR AND ACTIVITY LEVELS

WHEN Ictalurus BEGINS RAPID INCREASE

OF SELECTED TEMPERATURE

\begin{tabular}{lccccccr}
\hline & 0 & 1 & 2 & 3 & 4 & 5 & 6 \\
& & & & & & \\
& & & & & \\
\hline
\end{tabular}


about 30 minutes of the rapid temperature increase, run 3-6 fish had attained a temperature of about $22^{\circ} \mathrm{C}$. At that point, the rate slowed to almost one tenth of the previous rate. Run 3-7 altered its rate of increase at about $15^{\circ} \mathrm{C}$, dropping it to a nearly linear rate with a slope similar to that of run 3-6. Th1s rate was maintained to $26^{\circ} \mathrm{C}$ for run $3-7$, but final preferendum temperatures were not reached within the time of the experiment. Analysis of the flatter portion of the slopes in these two $3^{\circ} \mathrm{C}$ runs shows a good linear fit (See Table V).

TABLE V

ANALYSIS OF LINEAR SLOPE PORTION OF Ictalurus' RETURN TO FINAL PREFERENDUM

\begin{tabular}{lcc} 
Treatment & $3-6$ & $3-7$ \\
\hline $\begin{array}{l}\text { Time period } \\
\text { of analysis }\end{array}$ & $\begin{array}{c}100- \\
330\end{array}$ & $\begin{array}{c}170- \\
520\end{array}$ \\
\hline $\begin{array}{l}\text { Linear } \\
\text { Regression }\end{array}$ & $\begin{array}{c}\mathrm{Y}=21.4+ \\
.022 \mathrm{X}\end{array}$ & $\begin{array}{l}\mathrm{Y}=7.2+ \\
.037 \mathrm{X}\end{array}$ \\
$\mathrm{F}$ & $(1,23)=82$ & $(1,35)=815$ \\
& $\mathrm{p}<.001$ & $\mathrm{p}<.001$ \\
$\mathrm{r}^{2}=$ & .79 & .96 \\
\hline
\end{tabular}

It is also possible to fit an logarithmic curve to the increase in selected temperature as the fish return toward the final preferendum. Computer curve fitting to the data of run 3-6 over the period of temperature 
preference increase $y$ ielded the equation $\mathrm{Y}=15.2 \times \mathrm{x}^{0.109}$, with a correlation coefficient of $\mathrm{r}=.98$. The other runs at $3^{\circ} \mathrm{C}$ did not support this result, and it seems more 1ikely that the increase in temperature choice is a biphasic increase, rather than a logarithmic response.

Fish in runs 3-6 and 3-7 were allowed to stay in the gradient for over ten hours. During this time, the increase in their temperature selection slowed even further. The choices at that point seemed to show a fluctuation at that time over a range of $20^{\circ} \mathrm{C}$ to $26^{\circ} \mathrm{C}$. The period of these fluctuations appears to be in the range of one to three hours, and to be quite different for the two runs, a1though there is not enough data to analyze this. 


\section{CH APTER V}

\section{DISCUSSION}

The general behavior of Carassius and Ictalurus in the temperature gradient was similar, and generally predictable, given their known responses to thermal stress. Although attempts were made to remove all other possible motivators of behavior in the gradient, the fact remains that in some cases, factors other than temperature may have influenced fish location in the gradient.

Even in individuals with very different behaviors, negative skews frequently occurred in the temperature preference data. This is probably a normal function of movenent through the gradient. Since temperature preference is usually near the upper tolerance limits, longer excursions will be limited to the cold portion of the gradient. While this is one possible cause of temperature skewness in this study, an experimental bias is also introduced in the warm temperature limit of the gradient. Some $f$ ish spent much time near the warm end heat exchangers and probably would have spent time in even warmer water if given the choice.

The report that $f$ ish lose sensitivity to external temperature during prolonged exposure to constant temperatures (Norris, 1963) is difficult to confirm here, as all fish underwent similar acclimation regimes, with respect to temperature cycles. However it should not be overlooked that this could have had an effect on all of the data. Some fish did show a lack of 
precision in choosing a preference, with wide ranging and apparently random movement through the gradient. The truly anomolous behaviors, such as those in run 3-38, may indicate more of a problem in dealing with extreme cold. However, it is unknown why the other runs of $3^{\circ} \mathrm{C}$ acclimated fish did not display such quiescent behavior. It should also be noted that the high standard error in temperature preference data indicates much individual variation in runs $3-32$ and $3-38$.

The process of acclimation over a term of nearly three months can be observed in Carassius data at $3^{\circ} \mathrm{C}$. The first 14 days of acclimation show the continuing progress of acclimation, as judged by their acute temperature preference. After that time, the fish show their lowest acute temperature preference. At that point, further acclimation at $3^{\circ} \mathrm{C}$ seems to result in no further significant change in acute temperature preference, as seen over the following 36 days.

After acclimation to temperatures lower than the final preferendum, Ictalurus showed almost a step form of adjustment, Immsdiately entering water 8 to $17^{\circ} \mathrm{C}$ above the acclimation temperature. Then they showed little inclination to increase selected temperature for some minutes, remaining in the same area of the gradient. This is the period that is best defined by the term "acute temperature preference". After this period, a rapid increase in temperature selection began, bringing the fish toward final preferendum temperatures. Unfortunately, records of Carassius behavior were not discernible during the first 15 minutes of the runs, and interspecific differences in the timing of changes in temperature preference can not be 
analyzed. It may be that the initial rise in selected temperature of Ictalurus is due to the realization that warmer temperatures are available. As can be seen from the example of the tolerance zone (Figure 1), the acute preferred temperature after cold acclimation is above the acclimation temperature. The plateau seen next in selected temperature may represent the point at which temperature change becomes stressful. Since acclimation may take place on a time span ranging from instantaneously to seasonally, this could also describe the point at which a fast acting mechanism's compensation is overridden, resulting in stress. It is also conceivable that this lull is just a product of the experimental procedure, such as a brlef fear or startle response at the new situation. That this plateau represents the point at which temperature change is causing stress seems possible, since the time of acclimation at $3^{\circ} \mathrm{C}$ was a good determinant of the temperature at which the lag in temperature preference increase occurred. This period was also marked by high standard errors and a tendency toward higher activity, possibly indicating that fish were moving in and out of areas of stressful temperatures. This could be seen as stimulatory to a fast-acting acclimatory process, particularly if looked at in the light of the temperature harden ing process previously described. At the lower acclimation temperature regimes, the immediately preferred temperature correlated with previous acclimation experience, while at acclimation temperatures near $7^{\circ} \mathrm{C}$ and above, increases seemed to cause little change in the immedlate temperature preference of the fish. Possibly there is a greater lag time before the start of the acclimation process when the temperature perturbation is not extreme. 
Alternatively, the lower temperature acclimation may cause an increase in certain parameters of the changes that occur with low temperature acclimation, but not with intermediate temperatures.

Following this lull in the upward trend of temperature choice, fish then continued towand the final thermal preferendum. During this period of increase, the thermal history of Ictalurus was clearly a good determinant of the course toward the final preferendum. Al1 of the groups started toward the final preferendum at relatively rapid rates. However, fish from warmer acclimation regimes increased selection temperature a little faster during this period, and were able to maintain this rate up to the area of the final preferendum. While this may be a simple temperature effect of increased speed, activity and response, it may also indicate that they are not undergoing the temperature stress that those fish acclimated to $7^{\circ} \mathrm{C}$ and $3^{\circ} \mathrm{C}$ had incurred. All of these $\mathrm{fish}$ slowed their rate of temperature increase after a brief period of rapid increase. In each of these cases, the resulting rate of increasing preferred temperature seems fairly constant, and thus may represent the manifestation of another compensatory physiological adjustment occurring within the fish, limiting the upward preference change. Slopes in this portion of selected temperature changes, while not dependent on thermal history, did show a high variability. Speculatively, this could indicate that molecular synthesis, rather than electrolyte balancing may be responsible for the slopes observed during this stage of return toward the final preferendum, since the steady pumping of gill epithelial cells in response to the $\mathrm{pH}$ and electrolyte imbalances caused by a given temperature 
change would probably result in linear correlations with similar slope. Alternatively, changes in the constituent moleucules of the cell could be started at any point during the upward trend in temperature selection, and the resulting curve could have many different forms. This does not rule out the possibility that further cold acclimation resulted in some form of disability in dealing with osmotic or pH problems. Also, the concentration of enzymes capable of instantaneous compensation may vary in response to various acclimation regimes, resulting in different slopes of preferred temperature change. In order to more clearly resolve the question, it might be informative to perform such experiments in conditions of varying $\mathrm{pH}$ and electrolyte levels in the water of the temperature gradient.

The biphasic curve seen in the upward selection rate in cold acclimated fish is of less importance, or may even be absent in fish acclimated at the two warmer temperatures, so it is apparent that some physiological change has occurred, making the sudden change to warmer waters stressful. If problems with acid/base and Ion flux are ruled out, possiblities involve the synthesis of molecules appropriate to the new temperatures. A likely candidate for such rapid synthesis may be membrane lipids. As previously stated, this single change could have far-reaching effects in system functions. It is also conceivable that this change could occur without need of gene transcription, translation, or enzyme synthesis, through the action of pre-existing enzymes activated by temperature stress. Such a mechanism would clearly be adaptive in animals that are $11 \mathrm{kely}$ to undergo temperature stress, and it would seem a likely possibility if membrane lipids are truly the 
reason for the slow rates of preferred temperature increase seen in the cold acclimated $\mathrm{fish}$. It is also possible that gene expression could also take place within the time span here, since polypeptide products of gene activation can be found in cell cytoplasm in as little time as three minutes after gene induction (Lewin, 1987). The time course of this acclimatory response, several hours, is certainly too long to directly imply parameters of instantaneous acclimation.

Ictalurus from runs $3-6$ and $3-7$, which were allowed to stay in the gradient for over ten hours, were able to reach temperatures near the final preferendum. The apparent cycling of temperature selection during the last two to four hours may be the result of an ultradian period of neural or hormonal activity. The cycling, which had a magnitude of nearly $10^{\circ} \mathrm{C}$, may Indicate that these fish were still undergoing stress due to temperature change.

The effects of thermal history on temperature selection are signified by the lines relating acclimation temperature to acute temperature preference in both Carassius and Ictalurus. In both cases, the actual acclimation regime is a complex function of changing temperature over time. Since fish could be lethally stressed by sudden temperature change of the magnitude utilized in this experimental procedure, tank temperatures were lowered at the rate of about $1^{\circ} \mathrm{C} / \mathrm{day}$. Because of this, it is difficult to describe the acclimation regime in a quantitative fashion. However, three of the Ictalurus treatments represent different amounts of time spent at the same temperature, a somewhat more quantitative acclimatory regime. Even after 
four days acclimating to $3^{\circ} \mathrm{C}$, it is clear that the acclimation of Ictalurus is still in process, since both the temperature immediately chosen and the subsequent movement toward the final preferendum are continuing to change through the length of the acclimation. The nearly linear relationship seen here between time spent at $3^{\circ} \mathrm{C}$ and immediate temperature preference, contrasts with the line relating time spent at $3^{\circ} \mathrm{C}$ and the time taken to reach $25^{\circ} \mathrm{C}$, in which the difference between days three and four is greater than the difference between two and three. This argues against the first plateau seen in the $f$ ishes response in the gradient as being a result of instantaneous acclimation. If such were the case, time of acclimation at $3^{\circ} \mathrm{C}$ would have no effect on the immediate temperature chosen. Apparently, this represents some other physiological adjustment to temperature, and while different aspects of acclimation may take longer or shorter periods of time to achieve, they may also take varying amounts of time to diminish.

To summarize, the careful observation of fish activity in a thermal gradient after various temperature acclimation regimes may result in a fuller understanding of the processes involved. The above described procedures clearly showed some of the effects of temperature compensation and provided a sampling of the subsequent return toward the final preferendum. An initial increase in selected temperature followed by a plateau could clearly be seen in Ictalurus, and may have been present in Carassius. The consistency of the response and the time dependence on temperature indicate that 1 may well have a physiological basis. It is also possible that this could be a startle 
response to temperature, or to handling or other input due to the procedure. Peripheral temperature sensors are known to be present in fish and are surely of importance in orienting the fish to temperature differences (Crawshaw, 1976). Further integration with core temperature information and other inputs, such as blood oxygen tension and $\mathrm{pH}$ sensors in the vasculsar system could generate a fear response, resulting in the fish seeking thermal escape in lower temperatures. During the time of this resistance to upward movement In the gradient, $\mathrm{f}$ ish frequently tended to actually decrease their temperature choice. A similar mechanism could explain the second rate change seen in Ictalurus acclimated to lower temperature and allowed to return to their final preferendum. However, this change is not followed by a steady or decreasing temperature choice, but by a steady, continuing increase. It seems more 1ikely that another physiological problem relating to temperature change is manifesting itself. Since the continued upward change in choice is linear, it is possible that electrolyte regulation via gill function is the determinant of the rate. However, the difference in slopes between treatments of this parameter points to the possibility of a more profound change occurring, most likely molecular synthesis. The lipids are a good candidate for this change, and their synthesis could conceivably fit within the time frame here of a few hours. 


\section{BIBLIOGR APHY}

Allen, K. O. and Strawn, K. (1971). Rate of acclimation of juvenile channel catfish, Ictalurus punctatus, to high temperatures. Trans Am Fish Soc, 100:665-671.

Bass, E. L. (1971). Temperature acclimation in the nervous system of the brown bullhead, Ictalurus nebulosus. Comp Biochem Physiol, 40 A:833-849.

Beitinger, T. L. (1975). Diel activity rhythms and thermoregulatory behavior of bluegill in response to unnatural photoperiods. B1ol Bullet in, 149:96-108.

Belt1nger, T. L., Thommes, M. M. and Splgarell1, S. A. (1977). Relative roles of conduction and convection in the body temperature change of gizzard shad. Comp Blochem Physiol A, 57(2):257-259.

Bolaff1, J. L. and Brooke, H. E. (1974). Temperature effects on LDH 1sozyme distribution in skeletal muscle of Fundulus heteroclitus. Comp Biochem Physiol, 48B:557-564.

Brett, J. R. (1971). Energet1c Responses of salmon to temperature - study of some thermal relations in the physlology and freshwater ecology of sockeye salmon (Oncorhynchus nerka). Am 2001, 11:99-113.

Bulger, A. J. (1984). A dally rhythm in heat tolerance in the salt marsh fish Fundulus heterocl1tus. J Exp 2001, 230(1):11-16.

Caldwe1l, R. S. (1969). Thermal comparison of respiratory enzymes in tissues of the goldfish, Carassius auratus. Comp Biochem Physiol, 31:79-93.

Cherry, D. S. and Cairns, J. Jr. (1982). Blological Monitoring Part V preference and avoldance studies. Water Res, 16:263-301.

Cossins, A. R., Friedlaner, M. J. and Prosser, C. L. (1977). Correlations between behavioral temperature adaptations in goldfish and the viscosity and fatty acid composition of their synaptic membranes. J Comp Physiol, $120(2): 109-122$.

Crawshaw, L. I. (1975). Attainment of the final thermal preferendum in brown bullheads acclimated to different temperatures. Comp Biochem Physiol, $52 \mathrm{~A}: 171-173$.

Crawshaw, L. I. (1976). Effect of rapid temperature change on mean body temperature and gill ventilation in carp. Am J Phys1ol, 231:837-841. 
Crawshaw, L. I. (1979). Responses to rapid temperature change in vertebrate ectotherms. Amer Zool, 19:225-237.

Crawshaw, L. I. (1984). Low-temperature dormancy in fish. Am J Physiol, 246:R479-R486.

Crawshaw, L. I. and Hammel, H. T. (1974). Behavioral regulation of internal temperatures in the brown bullhead, Ictalurus nebulosus. Comp Blochem Physiol, 47A:51-60.

Crawshaw, L. I., Johnston, M. H. and Lemons, D. E. (1980). Acclimation, temperature selection, and heat exchange in the turtle, Chrysemys scripta. Am J Physiol, 238:R443-R446.

Crawshaw, L. I., Ackerman, R. A., White, F. N. and Heath, M. E. (1982). Metabolic and acid-base changes during selection of warmer water by cold-acclimated fish. Am J Physiol, 242:R157-R161.

DeW1tt C. A. (1967). Precision of thermoregulation and its relation to environmental factors in the desert iguana Dipsosaurus dorsalis. Physiol Zool, 40:49-66.

Fry, F. E. J. and Hart, J. S. (1947). The relation of temperature to oxygen consumption in goldfish. Anat Rec, 96(4):90-91.

Hazel, J. R. (1972). The effect of temprature acclimation upon SDH activity from the epaxial muscle of the common goldfish Carassius auratus - I. Properties of the enzyme and the effect of lipid extraction. Comp Blochem Physiol, 43B:837-861.

Hazel, J. R. and Prosser, C. L. (1974). Molecular mechan1sms of temperature compensation in poikilotherms. Physiol Rev, 54:620-677.

Heath, W. G. (1963). Thermoperiodism in sea-run cut throat trout (Salmo clark1). Sclence, 142:486-488.

Hutchison, V. H. (1961). Critical thermal maxima in salamanders. Physiol Zool, 34:92-125.

Hutchison, V. H. and Maness, J. D. (1979). The role of behavior in temperature acclimation and tolerance in ectotherms. Am Zool, 19(1):367-384.

Jobling, M. (1981). Temperature tolerance and the final preferendum - rapid methods for the assessment of optimum growth temperatures. J Fish B1ol, 19:439-455. 
Kavaliers, M. (1982). Seasonal and circannual rhythms in behavioral thermoregulation and their modifications by pinealectomy in the white sucker, Catostomus commerson1. J Comp Physiol, 146:235-243.

Kent, J. D. and hart, R. G. (1976). The effect of temperature and photoperlod on isozyme Induction in selected $t$ issues of the creek chub Semot ilus atromaculatus. Comp Blochen Physiol, 54B:77-80.

K11cka, J. (1965). Temperature acclimation in goldf 1sh: lack of evidence for hormonal involvement. Phys1ol 2001, 38:177-189.

Kowalsk1, K. T. (1978). Seasonal preferred temperature under controlled temperature and photoperlod. J Thermal B1ol, 3:105-109.

Lagerspetz, K. Y. H. (1974). Temperature acclimation and the nervous system. BLol Rev, 49:477-514.

Lew In, B. (1987). Genes, $3^{\text {rd }}$ Edit1on. John Wiley and Sons, New York, New York.

Mathur, D., Schutsky, R. M., Purdy, E. J. Jr. and Sllver, C. A. (1981). Simflarities in acute temperature preferences of freshwater fishes. Trans Am Fish Soc, 110:1-13.

Muller, R. and Fry, F. E. J. (1976). Prefered temperature of f1sh: a new method. J Fish Res Bd Can, 33:1815-1817.

Nelson, D. O. and Prosser, C. L. (1979). Effect of preoptic lesions on behavioral thermoregulat ion of green sunf 1sh, Lepomis cyanellus, and of goldf 1sh Carassius auratus. J Comp Phys1ol, 129:193-197.

Norr1s, K. S. (1963). The function of temperature in the ecology of the percold fish Gerella n1gricans. Eool Monogr, 33:23-62.

Otto, R. G. and Rice, J. 0. (1974). Swimming speed of yellow perch following an abrupt change in environmental temperature. J Fish Res Bd Can, $31: 1731-1734$.

Prosser, C. L. and D. O. Nelson (1981). The role of nervous systems in temperature adaptation of polk1lotherms. Ann Rev Physiol, 43:281-300.

Randa11, D. J. and Cameron, J. N. (1973). Respiratory control of arterial pH as temperature changes in rainbow trout Salmo gairdner 1. Am J Physiol, 225:997-1002.

Reeves, R. B. (1972). An Im Idazole alphastat hypothes is for vertebrate acld-base regulation: $t$ issue carbon dloxide content and body temperature in bullfrogs. Resp Physiol, 14:219-236. 
Reynolds, W. W. (1977). Temperature as a proximate factor in orientation behavior. J Fish Res Board Can, 34:734-739.

Reynolds, W. W. and Casterlin, M. E. (1978). Behavioral thermoregulation and diel activity in the white sucker, Catostomus commersoni. Comp Bioch Physiol, 59A:261-262.

Reynolds, W. W. and Casterlin, M. E. (1979). Behavioral thermoregulation and the "final preferendum" paradigm. Am Zool, 19(1):211-224.

Reynolds, W. W., Casterlein, M. E. and Millington, S. T. (1978a). Circadian rhythm of preferred temperature in the bowfin Amfa calva, a primitive holostean fish. Comp Blochem Physiol, 60A:107-109.

Reynolds, W. W., Casterlin, M. E., Matthey, J. K., Millington, S. T. and Ostrowsk1, A. C. (1978b). Diel patterns of preferred temperature and locomotor activity in the goldfish, Carassius auratus. Comp Biochem Physiol, $59 \mathrm{~A}: 225-227$.

Sat inoff, E. (1974). Neural organization and evolution of thermal regulation in mammals. Science, 201:16-22.

Shaklee, J. B., Chrlst1ansen, J. A. Sidell, B. D., Prosser, C. L. and Whitt, G. S. (1977). Molecular aspects of temperature acclimation in fish: contributions of changes in enzyme activity and isozyme patterns to metabolic reorganization in the green sunf 1sh, $J$ Expt Zool, 201:1-20.

Shingleton, M. V., Hocutt, C. H., Stauffer, J. R. Jr. (1981). Temperature preference of the new river shiner. Transact Am F1sh Soc, 110:660-661.

Shrode, J. B., Zerba, K. E. and Stephens, J. S. Jr. (1982). Ecolog 1ca1 significance of temperature tolerance and preference of some inshore California fishes. Transact Am Fish Soc, 111:45-51.

Side11, B. D., Wilson, F. R., Haze1, J. and Prosser, C. L. (1973). TIme course of thermal acclimation in goldfish. J Comp Physiol, 84:119-127.

Sm1t, H., Van Den Berg, R. J., K1jne-DenHartog, I. and Rozing, J. (1974). Some experiments on thermal acclimation in the goldfish (Carassius auratus). Nethl J Zool, 24 (1):32-49.

Spieler, R. E. and Noeske, T. A. (1977). Effects of thermocycles on body weight gain and gonadal growth inthe goldf1sh, Carassius auratus. Trans Am Fish Soc, 1006:440-449. 
Spieler, R. E. and Noeske, T. A. (1984). Effects of photoperiod and feeding schedule on diel variations of locomotor activity, cort1sol, and thyroxine in goldf1sh. Transact Am F1sh Soc, 113(4):528-539.

Sullivan and Fisher (1953). Seasonal fluctuation in the selected temperature of speckled trout, Salvelinus font1nalls. J F1sh Res Board Canada, $10(4): 187-193$.

Zar, J. H. (1977). Blostat1st1cal Analysis, $2^{\text {nd }}$ Ed1t1on. Prentice-Hall Inc, Englewood Cliffs, New Jersey, 170. 
The following table describes the temperature $\left({ }^{\circ} \mathrm{C}\right.$ ) of the tanks through the course of the experiment, along with occasional notes on the total number of $\mathrm{fish}$ in each tank and the transfer of $\mathrm{f}$ ish between tanks due to the loss of some experimental subjects. The time and tank from which fish were taken to be used in the gradient are also noted.

Day tank 1 tank 2 tank 3 tank 4 tank 5

\begin{tabular}{|c|c|c|c|c|c|}
\hline & & target & emperatures & & \\
\hline & 3 & 8 & 13 & 18 & 23 \\
\hline & & total start & ng number of & fish & \\
\hline & 29 & 29 & 28 & 28 & 10 \\
\hline $9 \mathrm{f}$ & $\begin{array}{l}23.5 \\
\text { Ish used } \\
\text { run } 1\end{array}$ & $\begin{array}{c}24.3 \\
9 \text { fish used } \\
\text { for run } 2\end{array}$ & 24.8 & 25.5 & 26.0 \\
\hline 2 & N.D. & 14.2 & 24.1 & 22.7 & 24.6 \\
\hline 3 & 22.2 & 21.1 & 23.0 & 23.2 & 24.2 \\
\hline 4 & 20.2 & 20.0 & 22.1 & 22.2 & 23.8 \\
\hline 5 & 19.5 & 18.5 & 20.3 & 21.2 & 23.2 \\
\hline 9 & $\begin{array}{l}17.8 \\
\text { f 1sh used } \\
\text { or run } 3\end{array}$ & 16.7 & 19.0 & 18.5 & 23.2 \\
\hline $\begin{array}{l}7 \\
\text { total } \\
\quad(29\end{array}$ & $\begin{array}{l}16.0 \\
51 \text { fish } \\
\text { from G2) }\end{array}$ & $\begin{array}{c}15.3 \\
47 \text { fish } \\
\text { (19 from G3) }\end{array}$ & $\begin{array}{c}17.1 \\
37 \mathrm{fish} \\
\text { (9 from G4) }\end{array}$ & $\begin{array}{l}18.0 \\
10 \text { fish } \\
9 \text { fish used } \\
\text { In redo of } \\
\text { run } 3\end{array}$ & $\begin{array}{l}23.0 \\
10 \mathrm{fish}\end{array}$ \\
\hline 8 & 14.3 & 14.7 & 16.2 & 18.0 & 23.0 \\
\hline 9 & 15.3 & 15.6 & 15.6 & 18.3 & 23.2 \\
\hline 10 & 13.5 & 14.0 & 14.2 & 18.0 & 23.0 \\
\hline
\end{tabular}




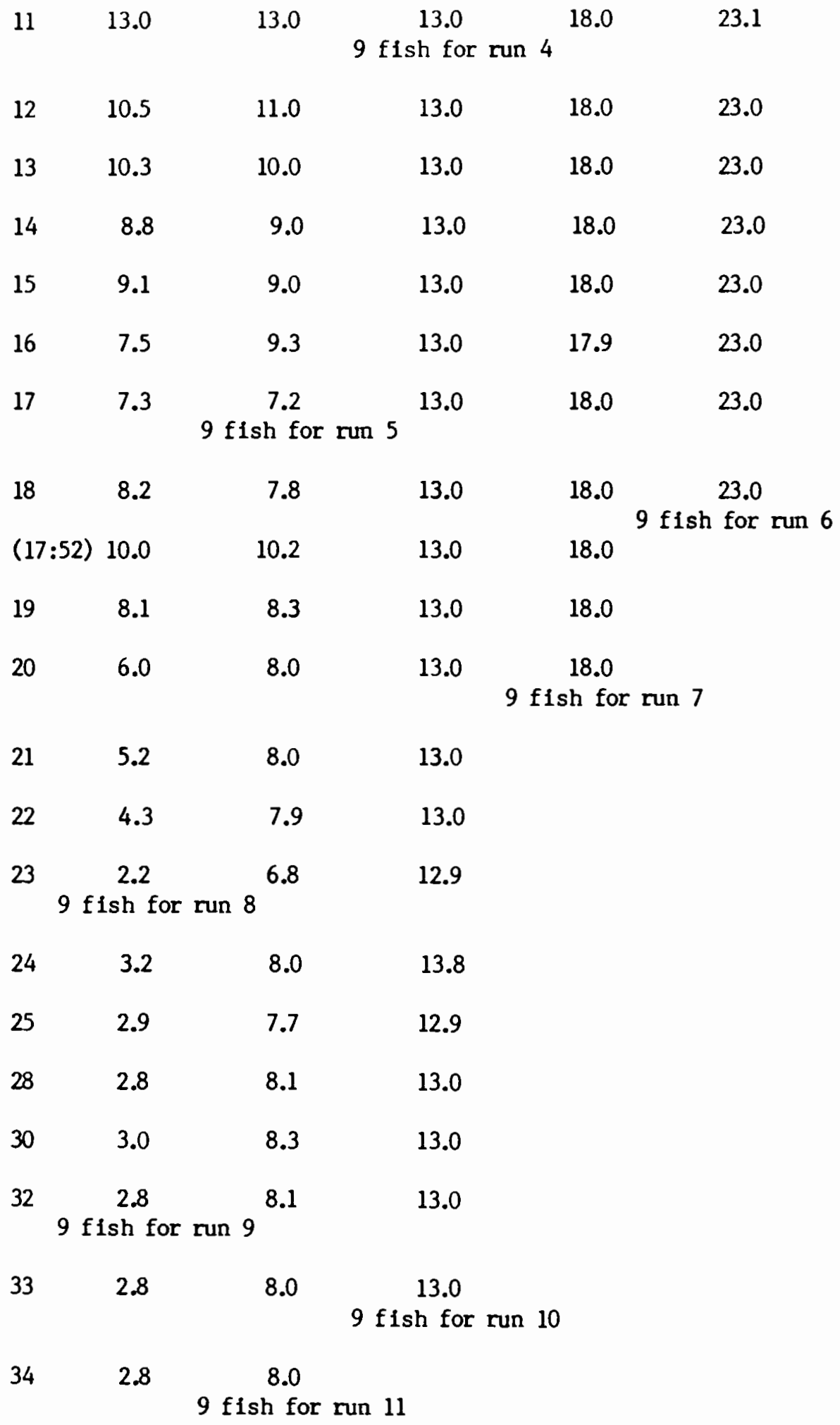


$\begin{array}{ll}36 & 3.9\end{array}$

$38 \quad 2.8$

$9 \mathrm{f} 1 \mathrm{sh}$ for run 12

$40 \quad 2.8$

$52 \quad 2.9$

9 fish for run 13

$\begin{array}{ll}73 & 3.8\end{array}$

$749 \mathrm{f}$ ish for run 14 